مهما بلغت قيمته الفنية والفكرية معا.فدرلسة الازياء

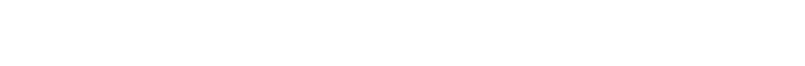
خصوصاً فى أوقات المنلسبت والأعياد والأحقالات المختلفة، الق تحدد لناطريقة ارتداء هذه الازياء. فمعلوماتنا عن تنك الازياء متناثرة في المصادر التاريخية والمعلجم وكتب الرحالة فهى تحتوى على الكثير

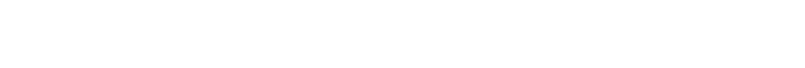
تسع البلمث في هذا المجل لان تلك المسميت يعوزها

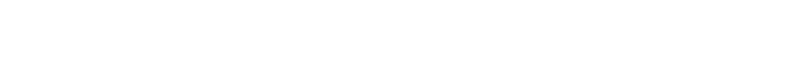

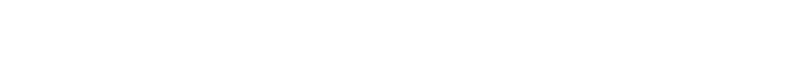

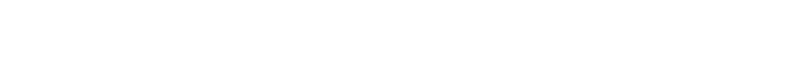

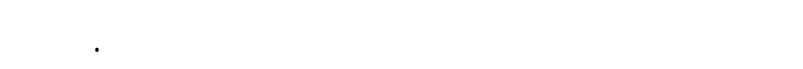

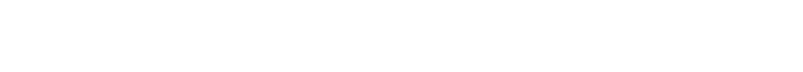
والنسج وغيرها للستكمل القص وبالتالي بسم صوئه

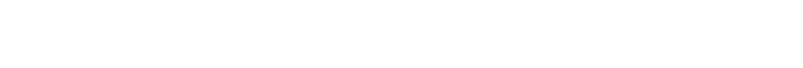
تفاصل هذه الازياء ولا المنلبة الق يرتندى فيها، ولكن

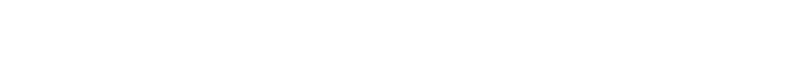
بلكمله. وبالرغم من أهميتها القصوى فإنها لم ناق العناية اللائقة بها من قبل البلحثن والمؤرخين وعلماء الآثار

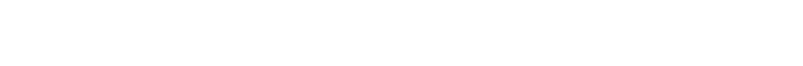
والدرلست القليلة المقرقة هنا وهنك. فلذك فأن أزياء العصر المملوكى تمتاز بالكثير من الخصائص الت صبغتها

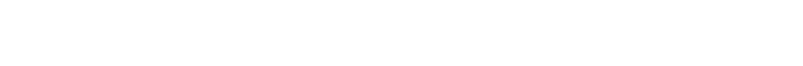
ازياء فى مختلف العصور وحتى عصرنا الحاله.

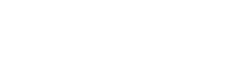

تعتبر درلسة تاريخ الازباء من الدرلسك الهامة الثي تتسم

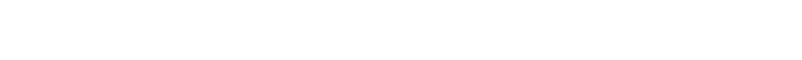

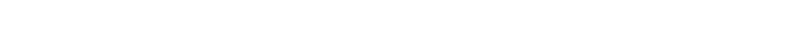

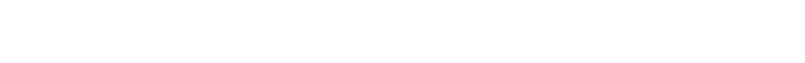

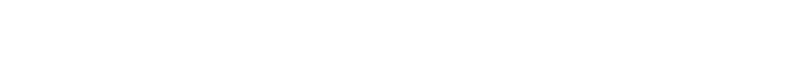

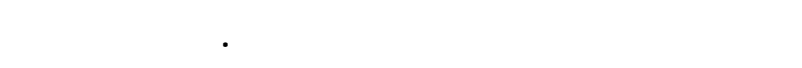
لازباء المملوكية بنوعبها المدف والعسكرى، من الموضوعلت الأثربة الهامة في تاريخ الحضارة العربية السلامية، لأن الازباء

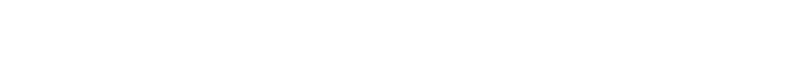

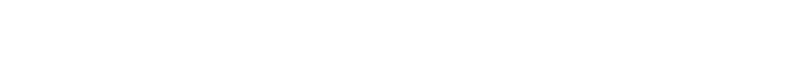

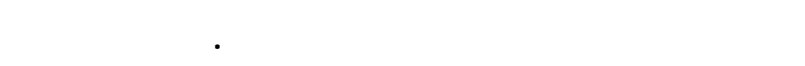

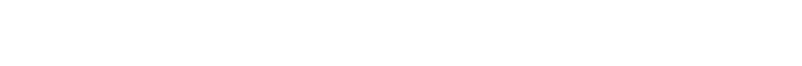
خصوصا ف أوقلت المنلسبلت ولأعياد والأحفلات المختلفة، الت تحدد لناطرقة الرتداء هنه لازباء. الفمد - ـة والمثكاة البحثية

تعتبر درلسة تاريخ الازياء من الدرلست الهلمة التي

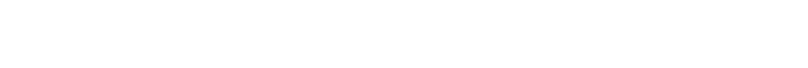
من مظاهر القفة الماية كالعمارة والفنون، وان معلوماتنا

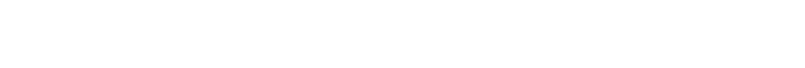

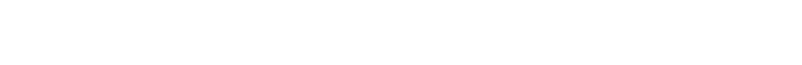
والمعلجم اللغوية واليضا من مكاتبكت موظفى الحكومة.

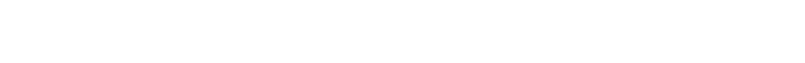

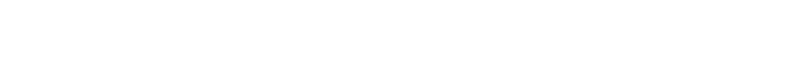

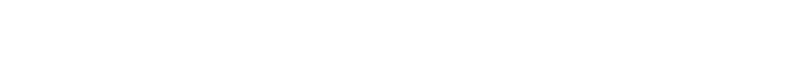

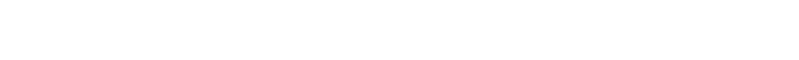

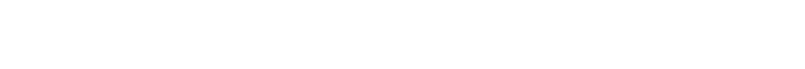

'مدس المعرد العاله للفنون الظبيقية التجمع الخلهس

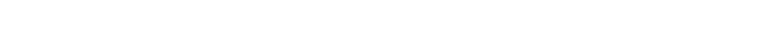


مصالحك البهث

تاربخية" التاريخ"

جملة من الاحول والاحداث الت يمر بها اى كائن ما ويهدف على الفرد والمجتمع، كما يصدق على الظواهر

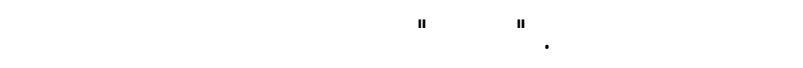
والظواهر التاريخية. تحليلية "حل الثئ" رجعه اله عناصره: درسه ليكثف خبايله. الازباء"الزي"

- الزى هو الهيئة أو المظر والجمع أزياء ( الصعاء المئ

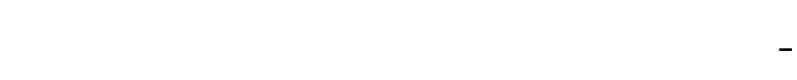

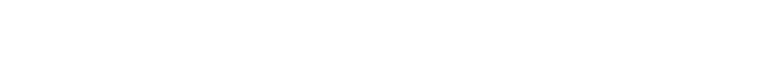

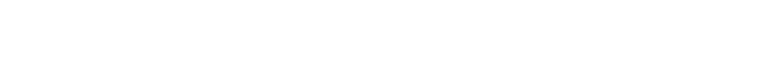
(r. • ( ) (7)

المماليك

يتضح من مدلول اللظظ فسه هم الرقيق الابيض. فهر

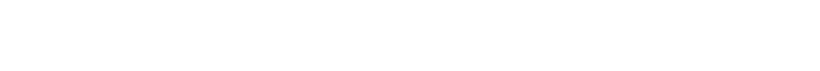
الجزيرة العربية لكثرمن قرنين ونصف القرن وبالتحيد من

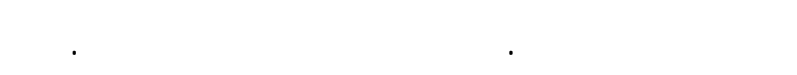
أن يسقروا بمصر والتي لأسوا بها دولتين متعقبتين كانت عاصمتها هي القاهرة: الأوله دولة المماليك البحرية، ومن البن البندين

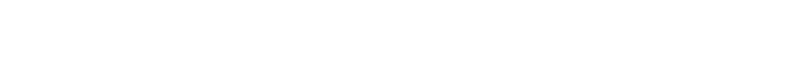

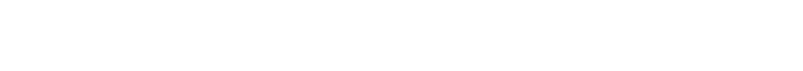
صلاح الين خليل الذي لستعاد عكا ولخر معاقل الصليبين

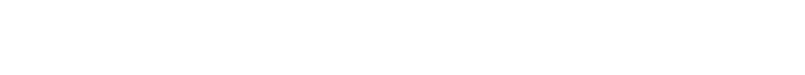

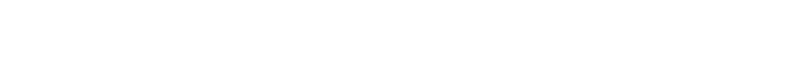

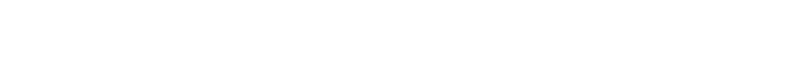
للثلم والعراق ومنها بغداد. فبدأت دولة المماليك البرجية الذن عرف في عهدهم أقصى لتساع لدولة المماليك في
يهوف هذا البهث إلى إعاة فحص جمبع العناصر التراثية المرتبطة بموضوع البحث وهو الازياء المملوكية.

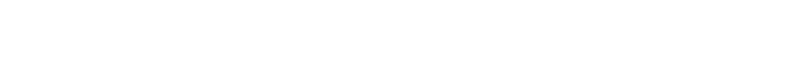
القرنيين من الزمن(VVV محاولة القصد منهاسد ثغرة هلمة فى مجل مهم تفقر اليه المكتبة العربية وهـ موضوضة المصدوعة الازياء او الملابس.

\section{لهمية البهث}

- تكمن اهمية البمث فى اعطاء صورة صادقة عنطررز الازياء المملوكية للنساء والرجل فى تلك الفترة.

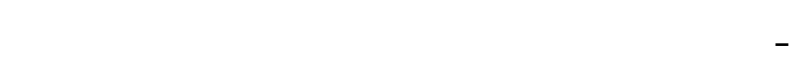

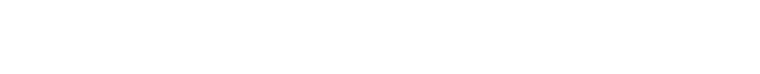

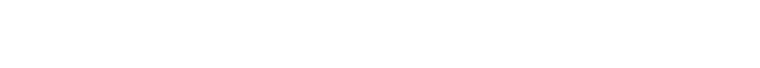

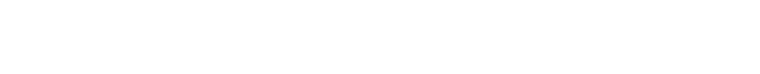

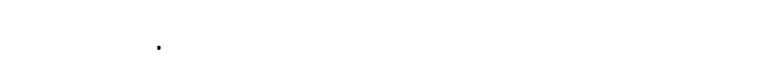

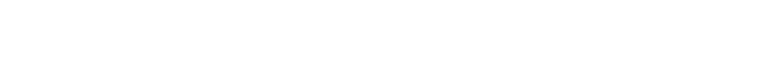

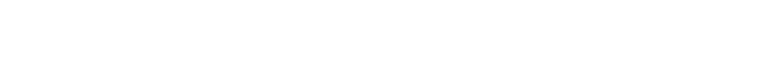

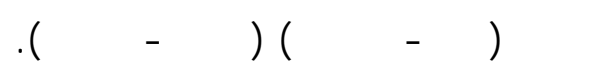

\section{الماوب البحث}

قيتصر هذا البهث على درلسة الازياء المملوكية فى

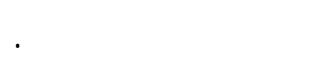

منه البهث

اتبعت الداوسة المنهج التاريخه والوصفى لتك الازياء

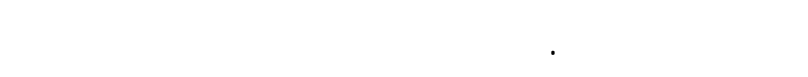
الازياء وأنواعها فـ بلاط سلطين المماليك والأمراء فى في

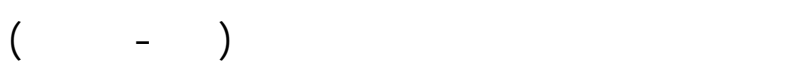

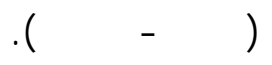
الوكت البهث - للشبكة العنكبوتية " الانترنت ". - المعبه الخاص بلسماء الملابس. 


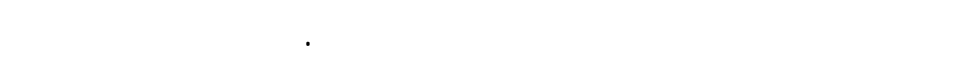

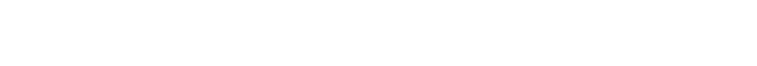
عصرهم عصراً جديداً وذلك ظرأ للأحداث التي ارتبت

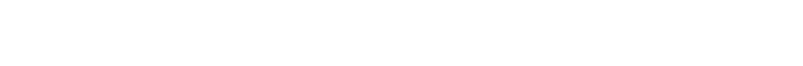

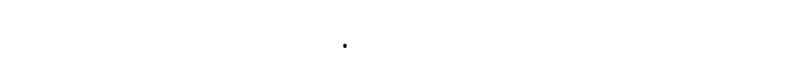

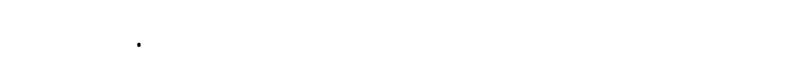
طومان باي أصبهت مصر ولاية عثمانية وقد ظلافئل

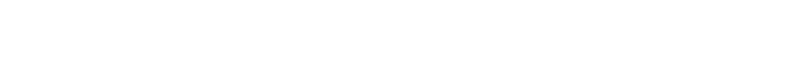
أمتجهن إلى الفتح والتوسع في البلدان في طريقهم إلى الى الى أوروبا(فت -11) وكلن للشطط التجارى فـ عصر المماليك فضل كبير فى التصل مجتمع الاسكندرية والقاهرة بكثير من ازياء

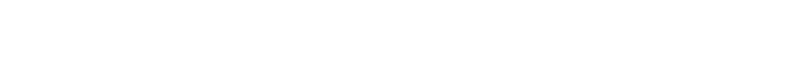

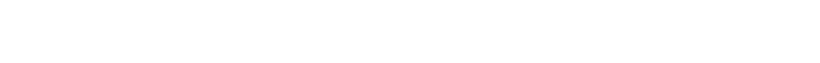

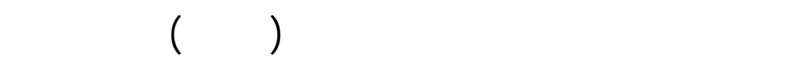
والغرب وبيعها فى الفناق والخانات والوكالات التجارية

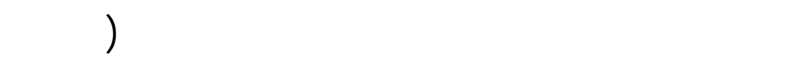

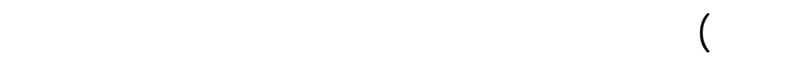

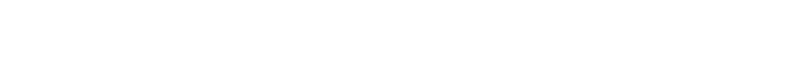

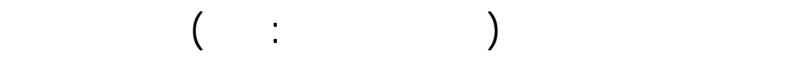

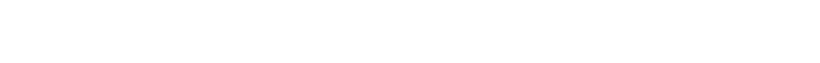

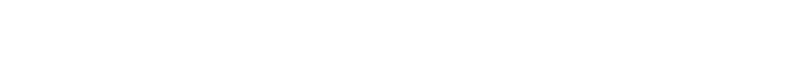
التترية ولعل من المنسوجت المصرية الوثقة الصلة

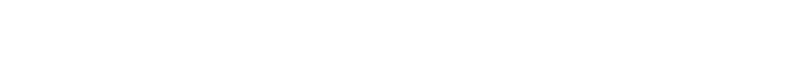

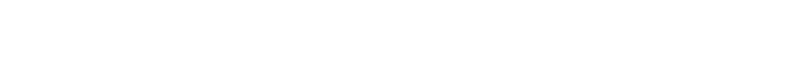

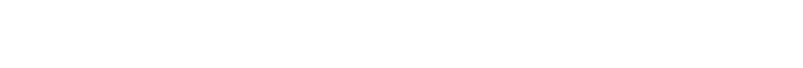

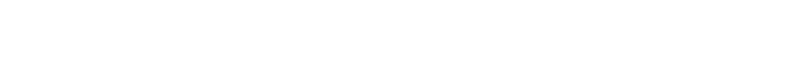

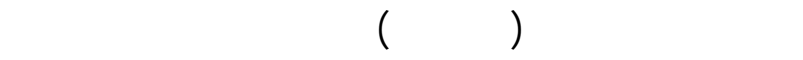

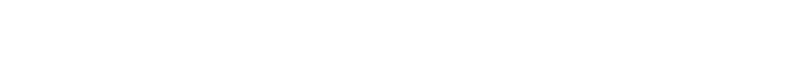

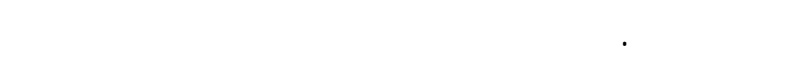
للجنود وزى للخلفة وزى للعلماءمن رجل الين المسلمين

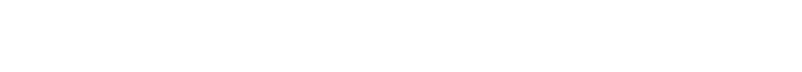
الدين ببسباي فاتتح قبرص وقانصوه الغوري وطومان باي. وكلن هؤلاء المماليك عبيدا لمنقمهر الأيوبيون، زاد

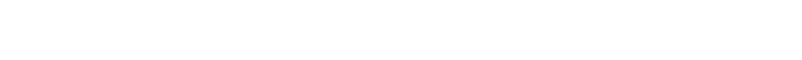

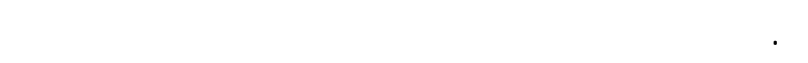

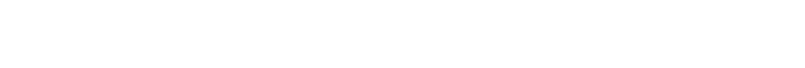
وفق قواعد صارمة في ثكنات عسكرية معزولة عن العالم

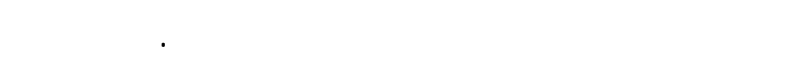
الظلم تمتعت دولة المماليك بنوع من الإسقرار كان نادرا آنذاك. قلم المماليك في أول عهد دولتهر بصد الغزو المغولي

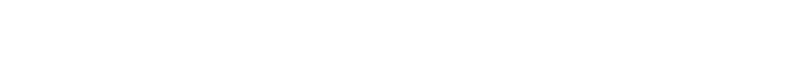

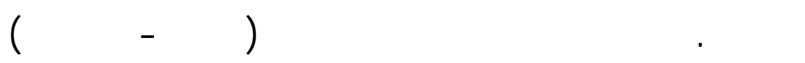
وللسلطين من بعده، ركز المماليك جهودهم على الإمارات

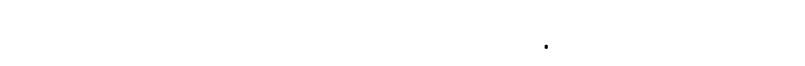
الصليبين في بلاد الشهلم(عكا).

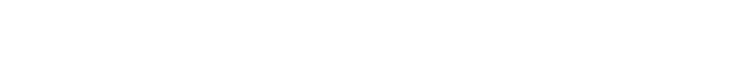
الشررق والغرب، وازدهرت التجارة ومعها القتصاد الدولة.

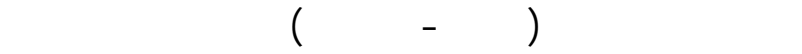

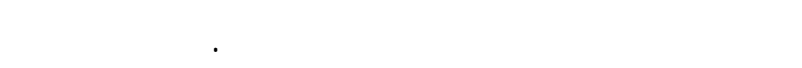

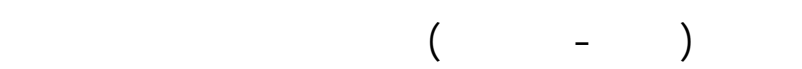

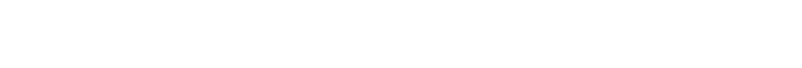

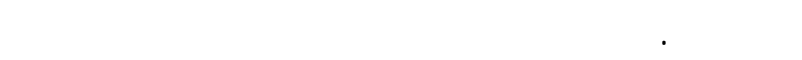

نحوقبرص (نت -())، خريطة (1)

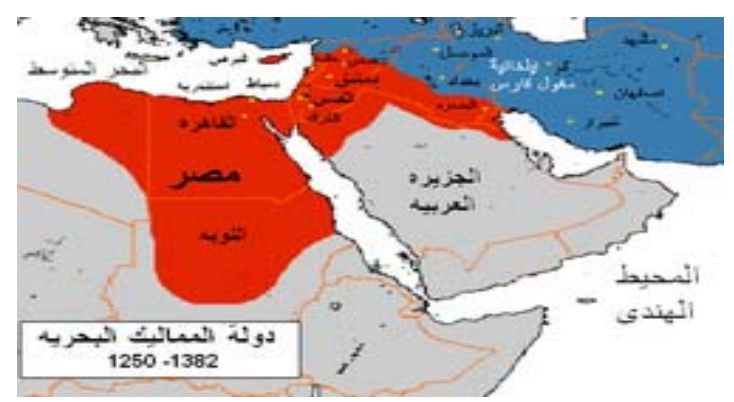

خربة 1 ـ دولة المماليك البحربة 
اللشخص ومركزه الاجتماعي. وفيما يله نستعرض الازياء

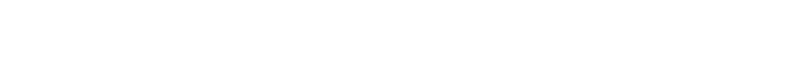
والدلخلية.

زى الخليفة: -

كلن الخلفاء العبلسيون يولطبون على اتباع نقاليد بغداد

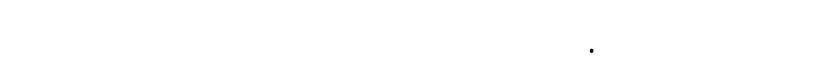

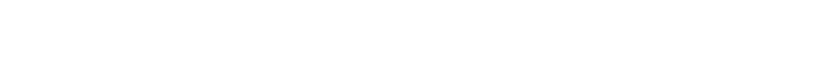
روحيا لكثرمنه زمنيا نيويا. وكانوا غالبا ما يرتدون زيهم

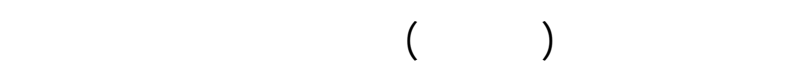

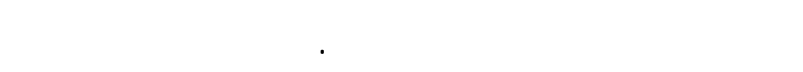

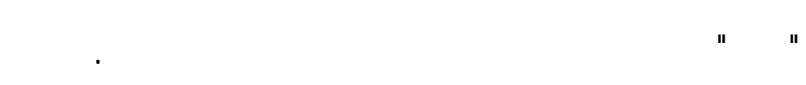
العصور اللسابقة للعصر المملوكى عبارة عن ثيد في يلبسه الحلكم فنسه ويطيه كهنية بعد ان يخلعه من فوق جسله. ويعتبرهذا التصرف الصلا بمثابة وعدشخصى بالامل لكثر منه رمزا للتكريم. ثم اصبحت خلعة الثرريف فى القرن

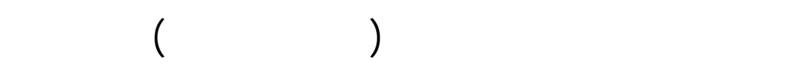
هذه العاة ان يخلع الخليفة الرداء الذى يرتنيه ويكسو بهابه

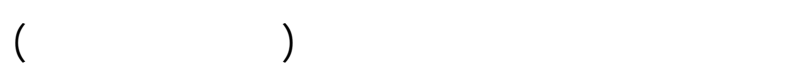
ويتكون زى الخليفة من قطع الملابس الاتية: -

| 1

البرة من ملابس النب(صله). ووصفها لين فى (اف

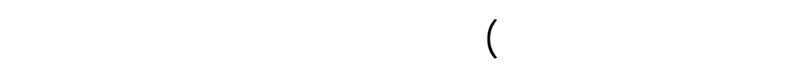

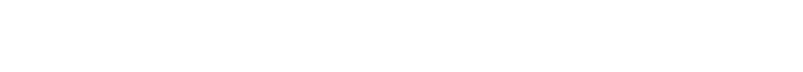

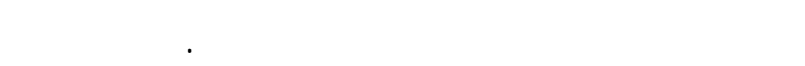
القملث فلسمر او رمادى ويبدو لن هذا النسيج كلن في النهاري

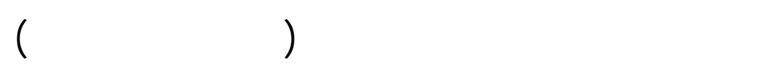

r - الفباء

وصفه دوزى عبارة عن لبلس خارجى للرجل فابس

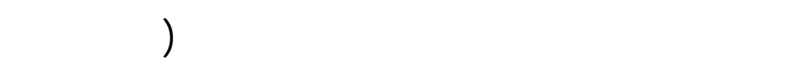

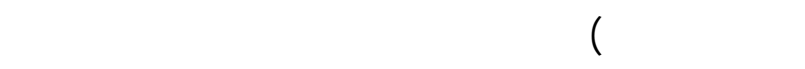
"كلملية" ضيقة عند الكم مفرجة الذيل من الخلف تبدأ من
وخلع للتثريف وزى الطوافف الدينية غير الاسلامية من

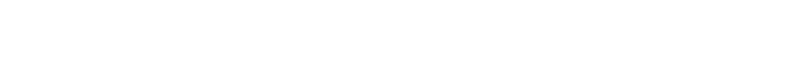
العسكرى كأبرز الازياء المملوكية المميزة لهذا العصر.

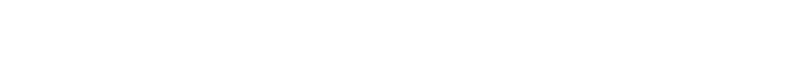
بزخارف نباتية وكتابلت نسخية عن طوريق القوالب الخشبية

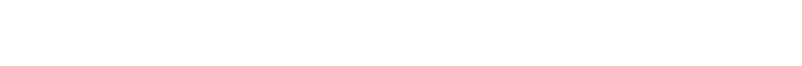

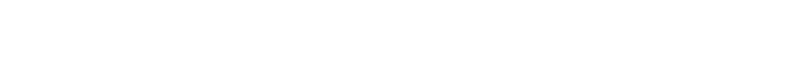
معينة والوان متعدة على الثوب عن طريق غراليتيت غرزة الرفى.

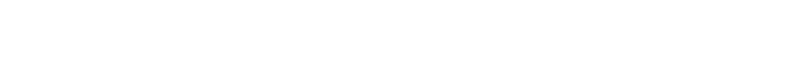
الاقشة الحريرية ذات الزخارف المفذة بالمكوك على نول فئل

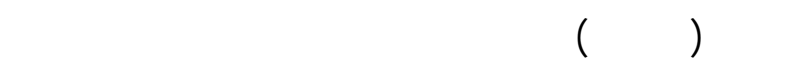
المعروفة بلم" الطردوش ".

\section{الزى المملوكى}

يعتبر

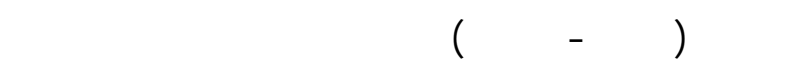
القوم ومازالت آثارة الماية من فنون وصناعلت تزخر

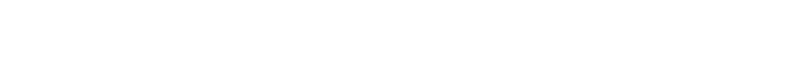
بالقاهرة. حيث ظورت صناعة الملابس في العصدر المملوكي وازدهرت فيه ازدهارَ كبيرًَ، وكلن هذا الظور نتاج العصور الأموية والعبلسية والفطمية للسابقة عليه، والتي الشتهرت بالترف والاهتملم المبالغ فيه بأنواع الملبوست، وقد تجمعت كل هذه الخبرات في العصر المملوكي وظهرت أزياء جدية تنلسب ذوق العصر(نت -9) ويسترعي النتبه مظم مؤرخي العصر المملوكي تنك العناية

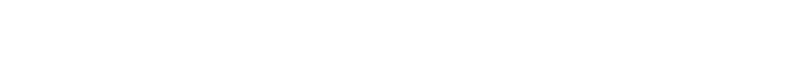

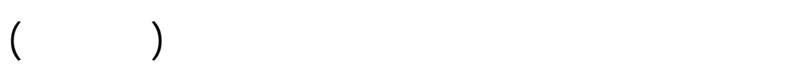
والخلعيين والفرائين. ولا يخفى على لُحد مدى الرخاء والثراء الذي وصلت اليه دولة المماليك، وظهر أثره بالطبع والعين في حياتهم العلمة والخاصة، ولستحداث تنوع كبير في أنمطا تلك الازياء عن طريق جلبه المماليك من موطنهم الأصلي لَّيا الوسطى، وكانت ازياء الرجل تختلف هسب مكانة 
يانى بصيرا والتون باهلكم لجمعين". ويمتاز القميص بوجود

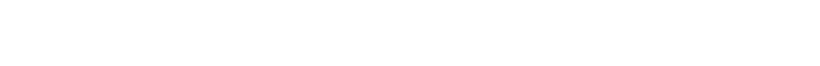

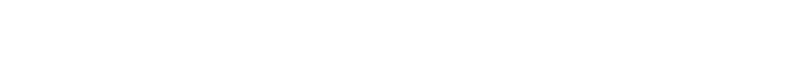

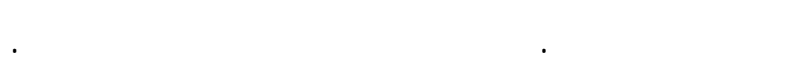

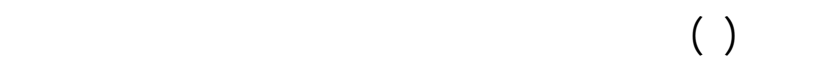

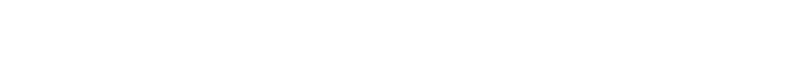

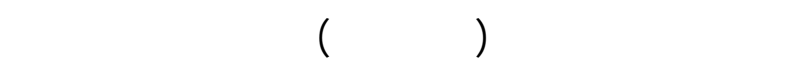

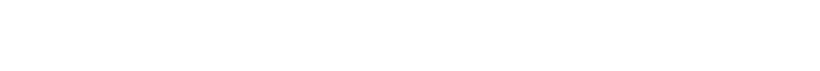

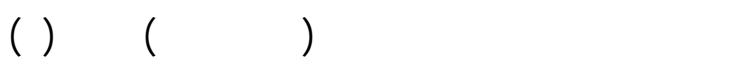

$$
\text { ع - غاء الرئس }
$$

كان غطاء الرئس عند الخلفاء يتكون من عملمة مدورة

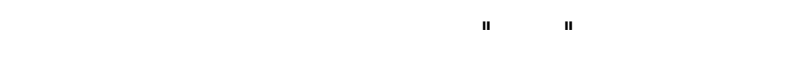

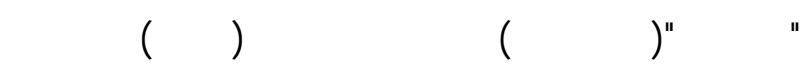

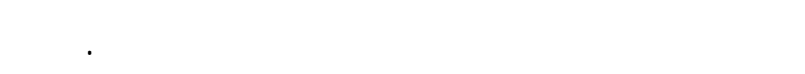
المنلسبت الرسمية والدينية ارتدى الخليفة" العملمة البغدادية المبلية

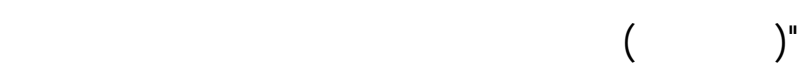

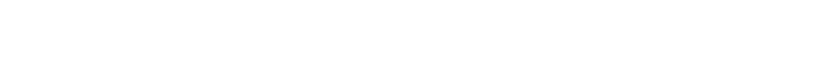
زركشة بيضاء. وقرأ لحيانا ان ملابس الخليفة لم تكن كلها

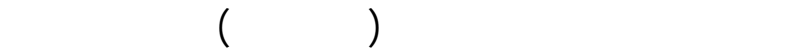

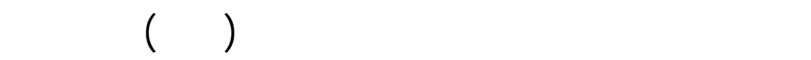
المقريزيز(وصف مصريجrاص - مץ) الن ملابس المراء والجنود وللسلطين المماليك اليلم الدولة الجركسية هـ القبية المهابية

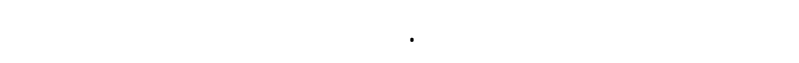

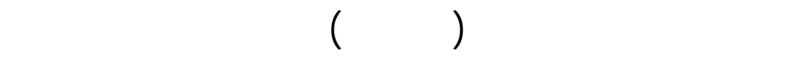
اللسطان المنصور قلاوون الطل لبس المّ الضيق وان البن البنه

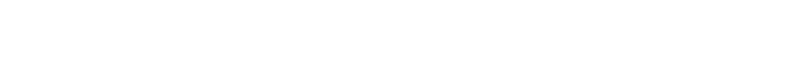

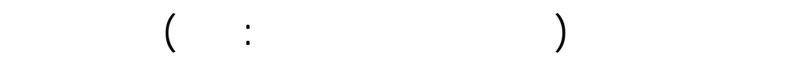

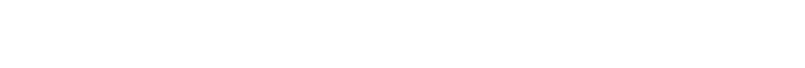

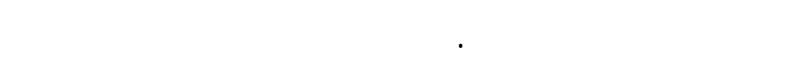

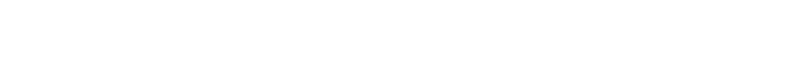

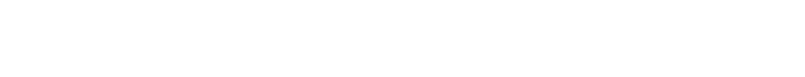

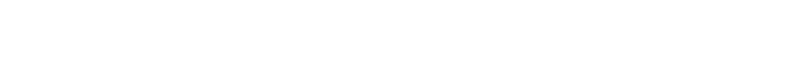

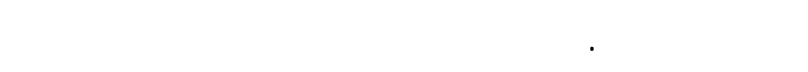

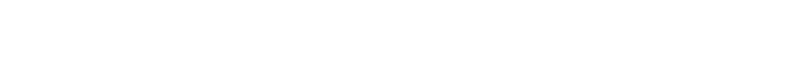

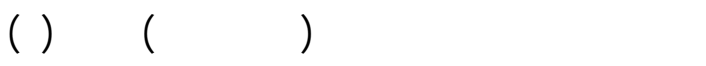
r - الفميص والرداء جاء نكر القميص فى القرآن الكريم فىسورة يوسف سوداء دائما.

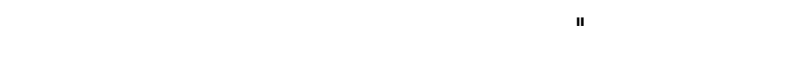

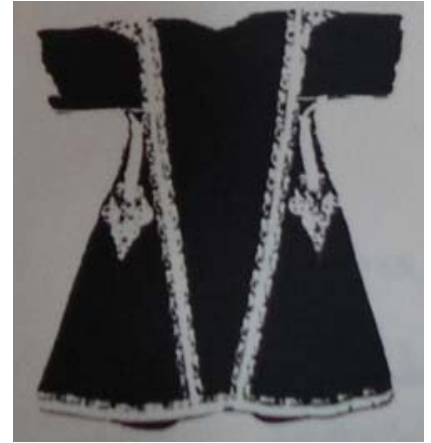

القباءa الخل

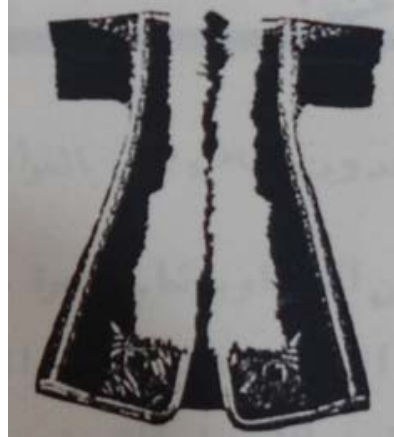

الفباءمن الاملم

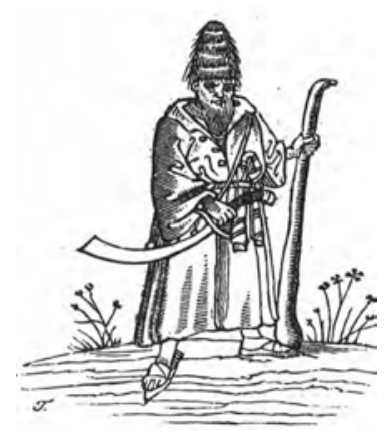

شال I ـ صورة لنطمن الازباء الفاهربة عن رحلة الرنولدفهن هارف وهل تمل لماءل لحد المراء المماليك يرتح اللثربوث هارف 


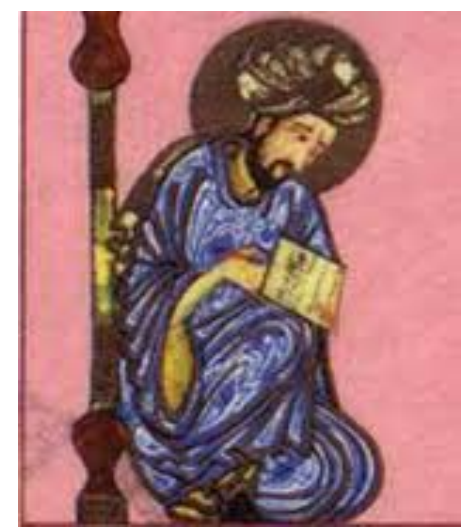

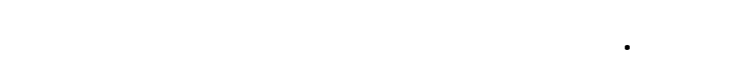
للسلالنسليملن المطنبل وفيها نرى الازب اء التير ة الرداء والهمامة الكبيرة ذلت الهنبة.

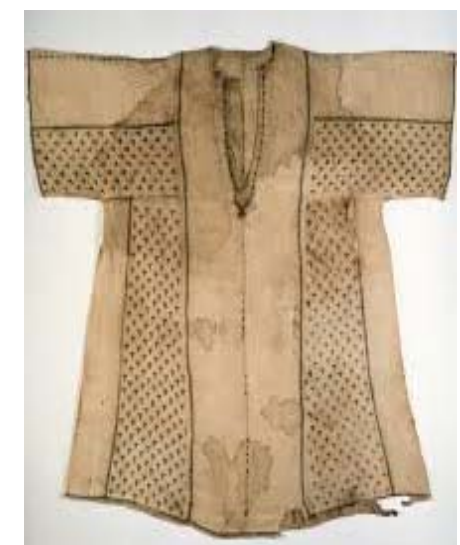

شكى r.قميص سن المصر المملوك يرجع الل الفرن

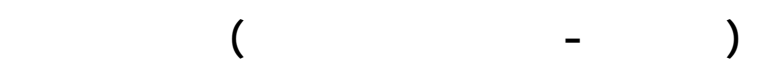
الحربر المثق ومنين بزخاف متنوعة. وبلق عليه ثوب تحتلف - تحتلنية متفف الفن السلالف بالفلهرة.

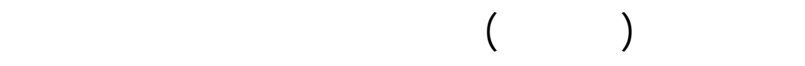
تبعا للغرض المطلوب لستخدامها فنجد ان ملابس السللن

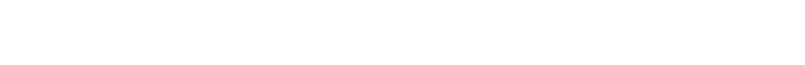
عسكرى. والجبة كالت من ضمن الخلع القى ينعم بهابها

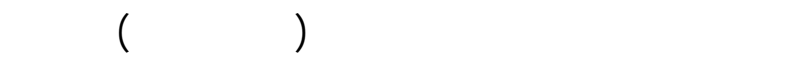
العملمة من طراز لم يسق للمير ارتداؤة. وملابس تتبويج

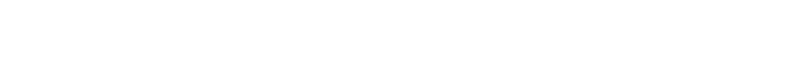

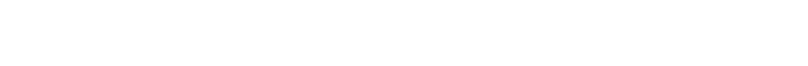
من النسج المذهب المزركث ودراعة او فرجية بفنسجية

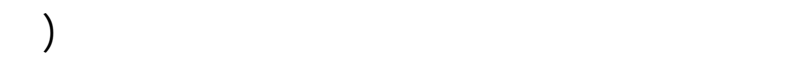

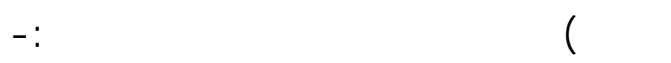

| 1

كلن شعار اللسطنة الرسم عبارة عن عملمة سوداء

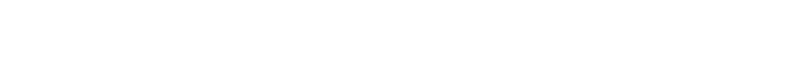
بداوى. لما اللون اللسود وهوشارة الولاء للخلافة العبلسية، منداء

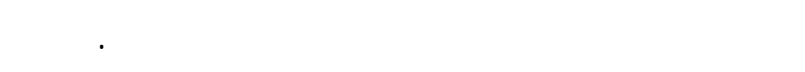
الخلفاء العبلسيون يحتظون به مع الستثناءات قليلة جدا. والعملمة المدورة كانت لحدى للثعائر للسطانية وكانت
وفى حفل تتويج الملك المنصور محمد بن قلاون كلن

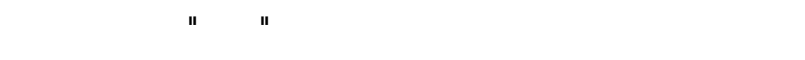

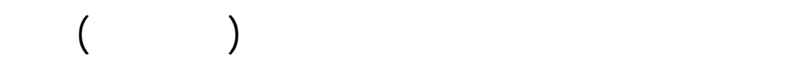
خلال حكم للسلطين الجرلكسة حرم على الخليفة ارتداء ثُوب الخلافة فكلن يرتدى لحيانا ملابس الطبقة العسكرية

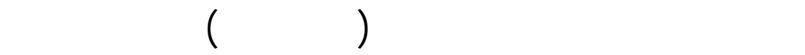

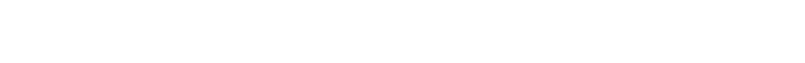
او نماذج مبسومة له ظرا لمكانة الخليفة الرفيعة. ولستمر الخليفة فى ارتداء الملابس العبلسية.

\section{- ز5 السلن -}

تنظلب المولكب للسطانية من للسطلن لبس افخر الثيب

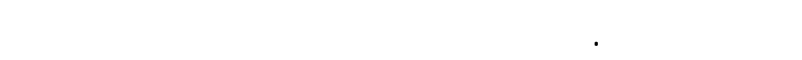

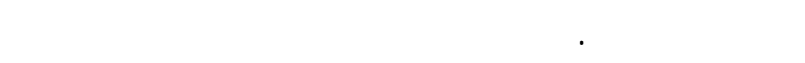
قميصا يعرف بلم" القمجون"عبارة عن قميص قصير بلكملم

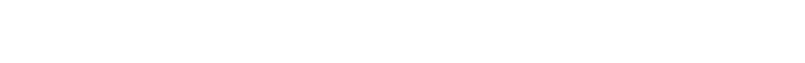

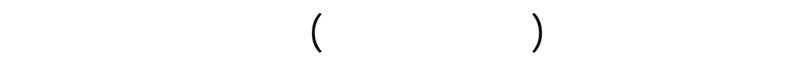
وذاع صيته بعد ذلك في اوروبا فاصسح موضة لدى الفرنجة. وليضا ارتدى العملمة وللسترة ولخفافا سوداء 
وبالرجوع اله الاثار المسلمية وجد ان الدراعة كلفت هـ ن

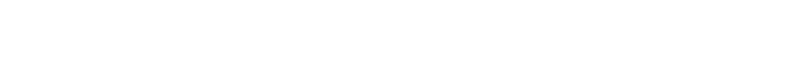

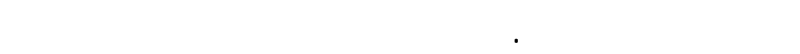

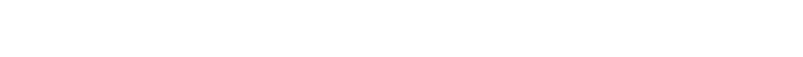

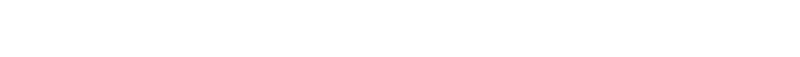
عند الرسغ(1، صوبr()،شكل(0)

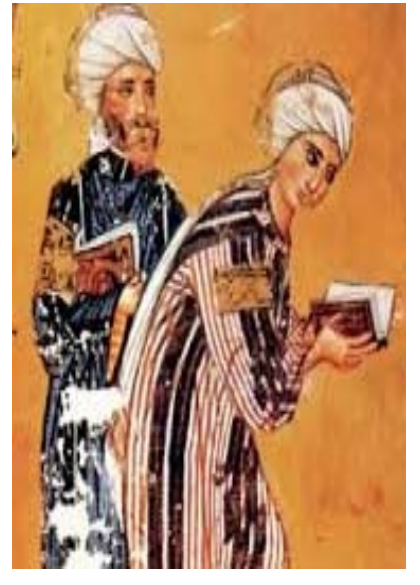

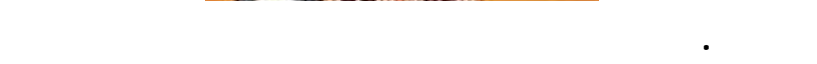
الراعة - الممالمة. * الحبة *

على مسب وصف دوزى بالهه ملبوس يرقى اللى العهود

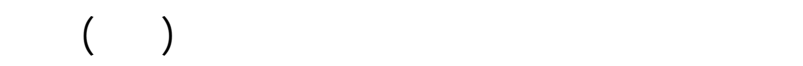

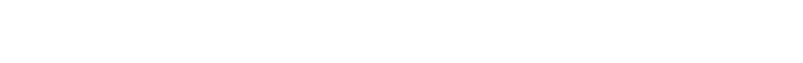
الخلفية اقصر قليلامن الجهه الملمية. يلبسه البعض مسبلا حقى الاقدلم ويرتنيه البعض مسبلا حقى منتصف اللساقين. وممكن ان تكون من التطن او الجوخ وتبطن الجبة في الفيل

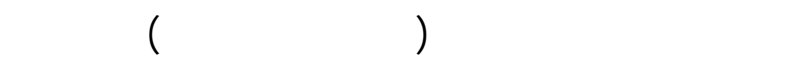

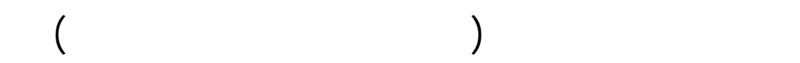

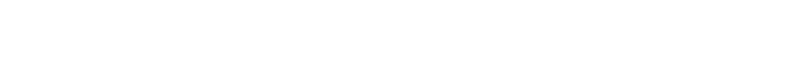
القنطان. ردنا الجبة قصيرلن بالنبة لرنف القنطان وتطن

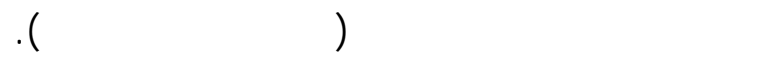
* الفرجية جمعها فرلجه، وهى نوع من الاقبية عبارة عن ثُب

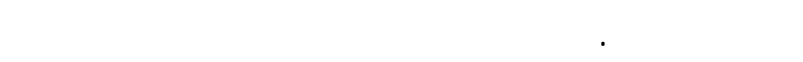

تشكل فى الققية جزء من ثيل الثثريف الملكى اى "خلعة

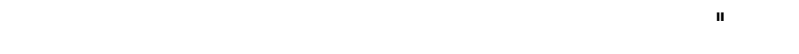

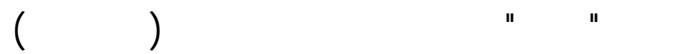
r - الجبة الوالدراعة الو الفرجية تنك الملابس لا ترى الا على المشابخ وحدهم وسنشرح بالفصيل شكل كل قلعة من تلك المابس الابس على حله (ع) (ع) (ع) (1)

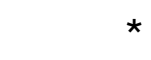

يعلمنا المقريزى (تاريخ السلطين والمماليك، جا، قا، المراء

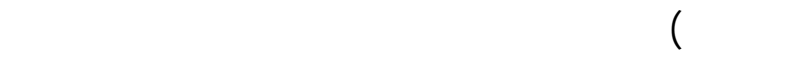

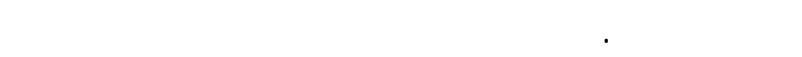

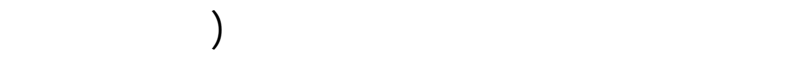

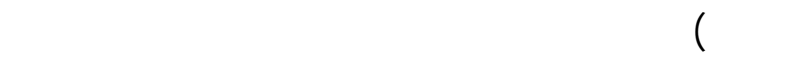

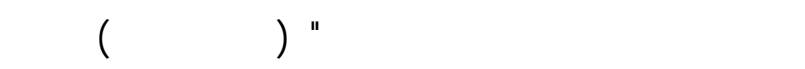

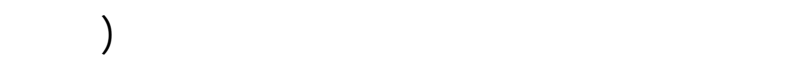

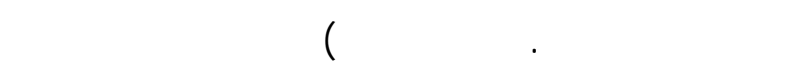
اله كان يلبس الدراعة المصنوعة من قملاث لحادى اللون.

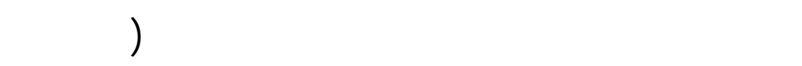

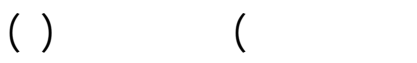

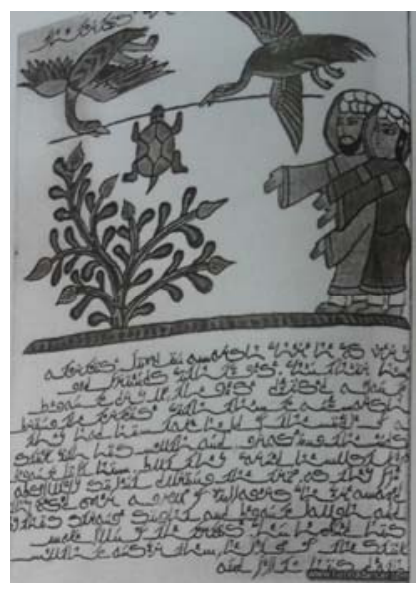

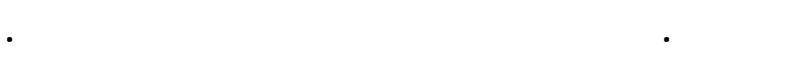

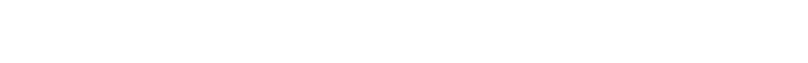
الانية الدراعة - اللسرول - الف - الممامة الصغيرة 
ازباؤة الثناء المولب المللانية

يرتندى المسلطان اثثناء المولكب للسطانية زى المير غظيم مؤلف من" كلملية" من المخطل الاحمر يحيطها فراء اللسمور

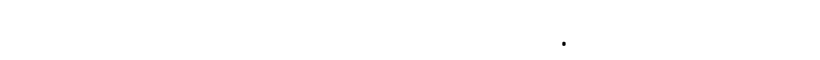

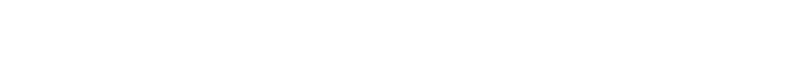

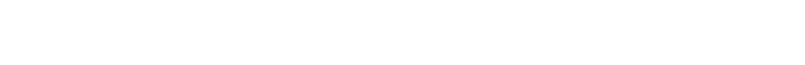

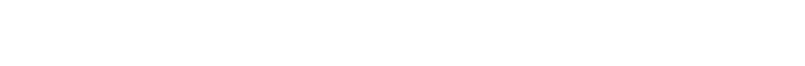
فخم مل المخطل الاحمر اوالصوف الازرق ويحطيها الفراء ولها قلابت من الفراء واله جالب تبطينها بفراء اللسمور

غاله الثن.ششك (v)

لما لبلس الرلس فكان يرتدى عملمة صغيرة يطلق عليها

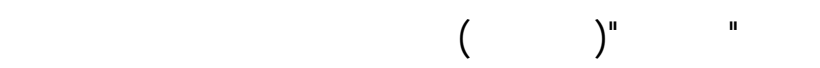

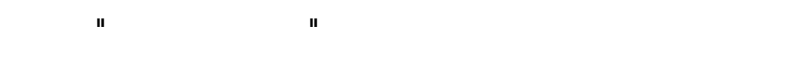

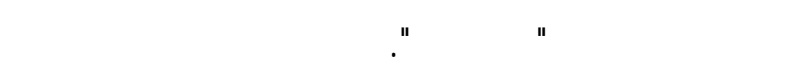

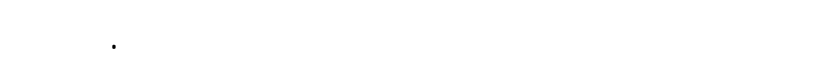

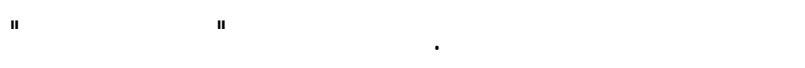

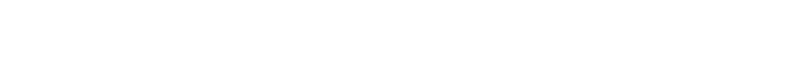

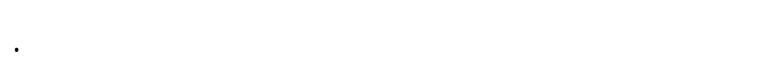

العلماء بالفرجية والنوع اللثثر النقة منها هو النى يقمه للسطان كمنح وهو مططن بفراء للسنجلب الرمادى والمزين المنان

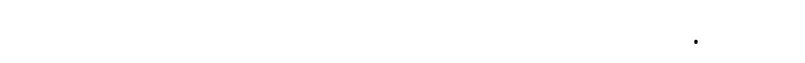

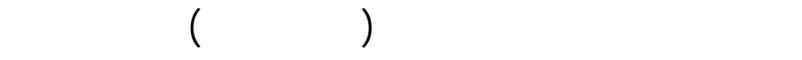

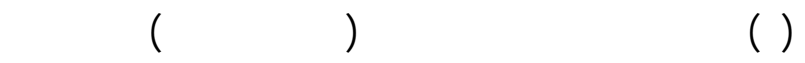

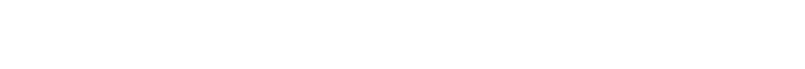

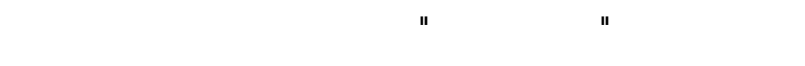

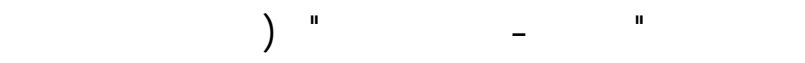

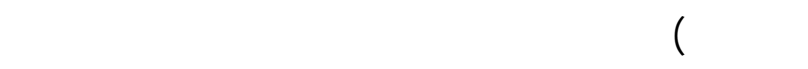
كتست شهرة ولسعة جعلتها تحطل اله الإطار النائية

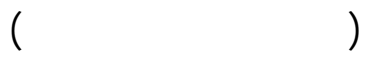

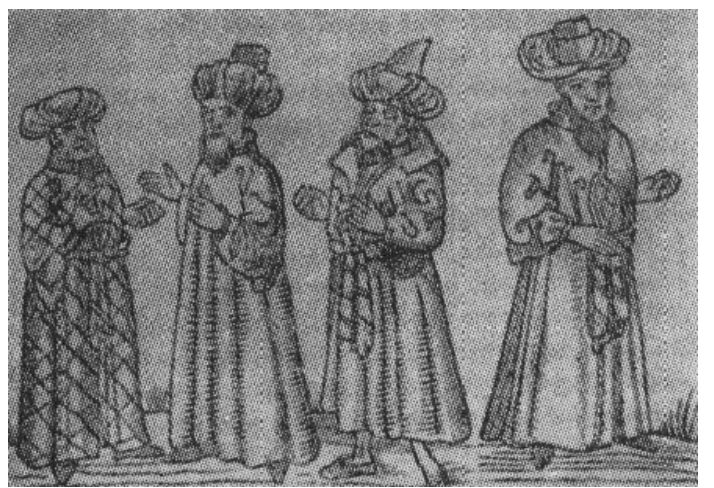

ششل 1. شور لانملامتنوعة من الملابس الفاهربة فم

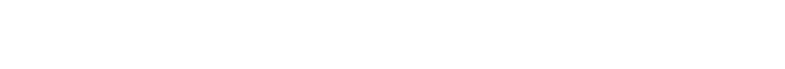
لازباء الانية الجبة - الغرجية - الممائم للأل النمة.
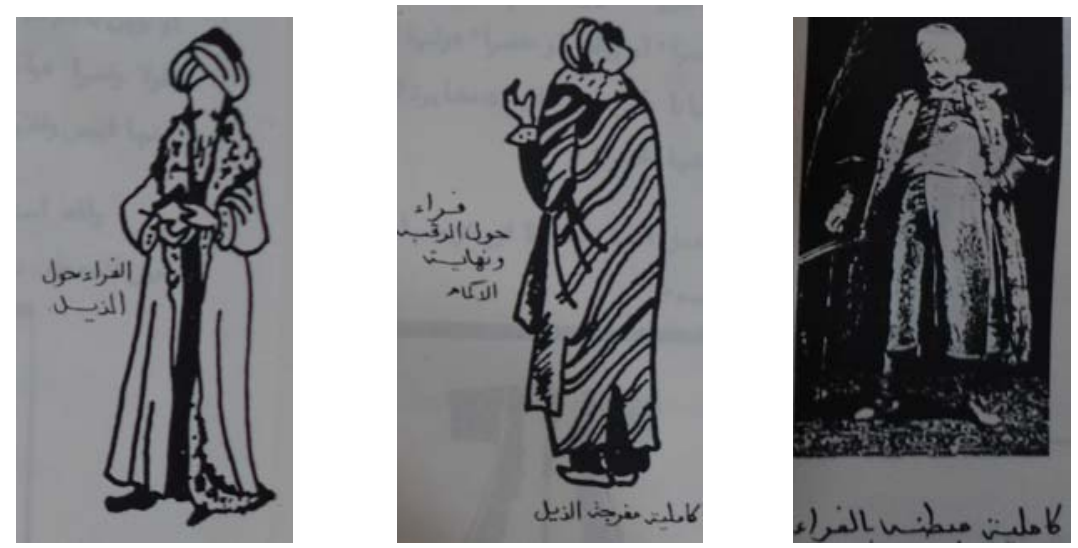

يشك v. الشكل الكاملية 


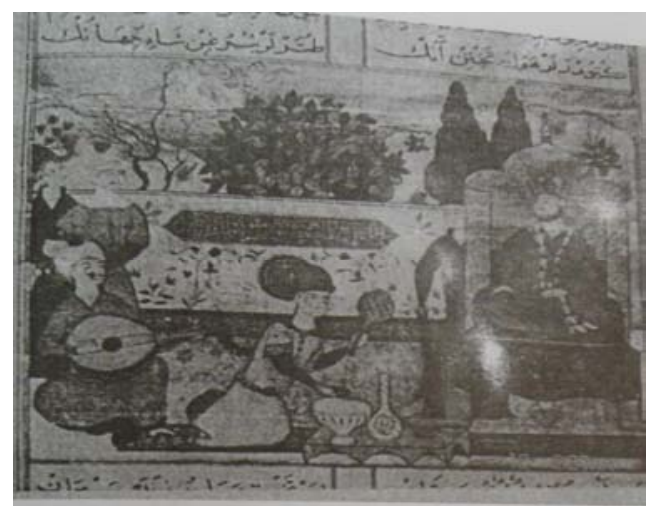

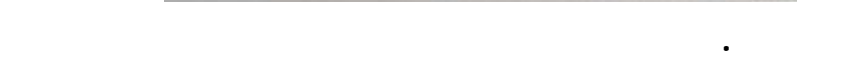

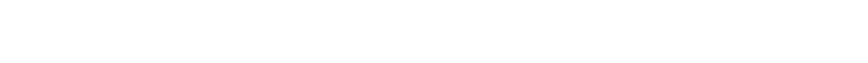

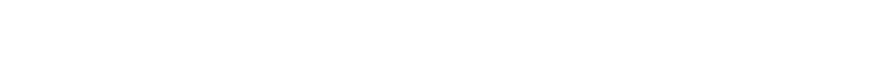

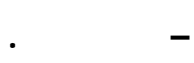

العسكر يلبسون على رؤوسه كلوتة صفراء مضربة كلماء تضريبا عريضا ولها كلاليب بغير عملمة فوقها وتكون

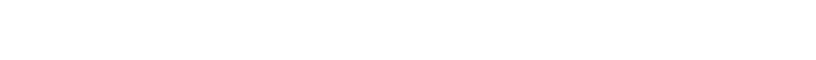

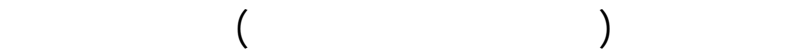

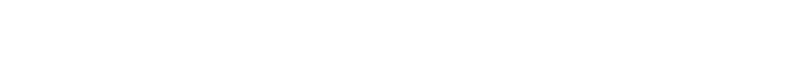
عونه من تأية فريضة الحج فحق ذلك الحين كلن المماليك

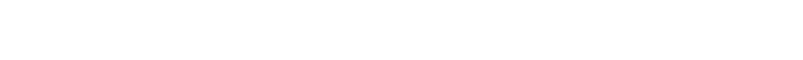
ع) ترسل طويلة "بأرخاء ذوائب الشعرب

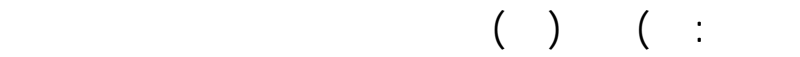
الاثشرف خليل بدل الكافتلت الجوخ والصفر ووسم لجمبع

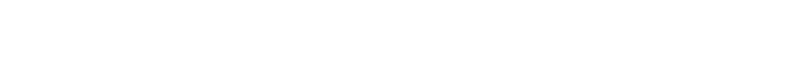

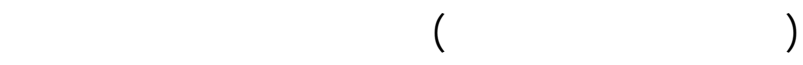

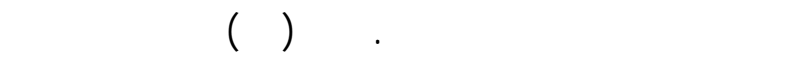

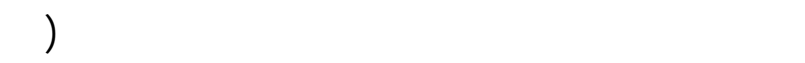
صوץ) وفى بعض المنلسبت كلن يلبس رداء فوق ملابسه يسم "قباء" ويصفه المقريزى(وصف مصر، جr جr،

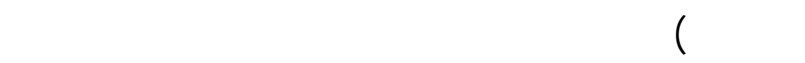

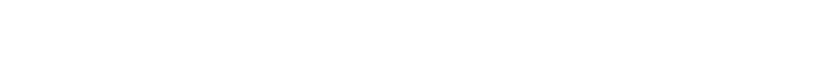

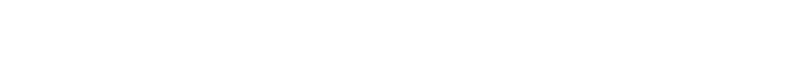
ذلك(ص/F) يعلمنا نفس المؤلف ان اللسطلن المنصور

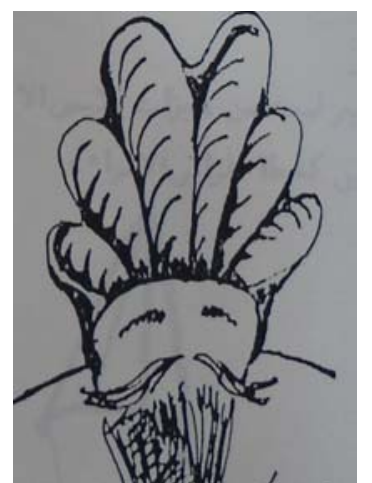

شكل م.شكل التخفيفة الكبيرة
وكانت التخففة الكبيرة بقرونها الطويلة نوعا من اغطية الرلأس القيلة. وقد اعتاد للسطلن الغورى لبس تتخفيفة

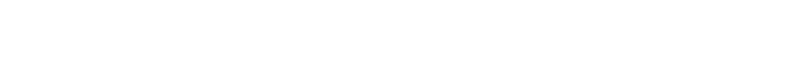
ارتداء التغفيفة الكبيرة بقرونها(ع،صاسَ) ونشاهد الناعورة فى عدة صور من بسم فناف الطاليا ولعل افضلها فى صورة حفل لسنقبل فسفير البندقية. وفى اثناء الموكب للسطافن كلن يرتدى للسطلن" تخفيفة صغيرة ملساء" وسلارى. ويتضح من ذلك النه كلن يوجد نوعلن من العمائم القى من نوع التخفيفة الصغيرة حيث النه

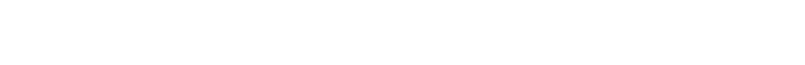

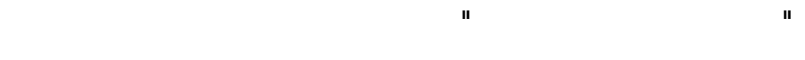

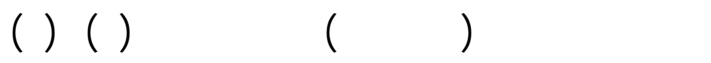
الهلفتاd وكلن يرتدى سلطين المماليك في الاحقالات الرسمية

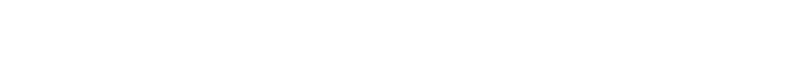
التلسع الهجرى(ع، صץّ) ووصف دوزى الكلفتة بانها طقية تؤلف هيكل العملمة وعلاوة على ذلك فانها نفس الهن الكلمة كالوت. وهذا الجنس من الطاقية لم يكن يلبسه الا رجل الطقة الرفيعة. وقرأ لدى المقريزى(وصف مصر،

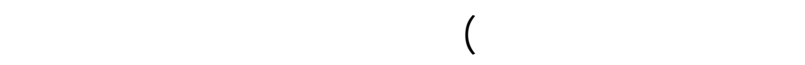


مج9، جr، صع () ثم يرتدون فوقها "الاقبي ـة الإس للمية" وعنئذ يشد عليها للسف من الجانب الايسر، لما الص -واق المان والكزلك فيشدان اله الجانب الايمن. وكما يستل من لسماء المعطف التترية فسها لن هذا الثوب كلن من اطل لجنبى وسمه كذلك لانه بدلا من عمل الثقة المس نقيمة القلييي ـة للاقمصة الت كانت تلبس فى عصر الفطميين كلن للاقبية التترية كمران تلف الصدر من اليسار اله اليمين وكلن هذا

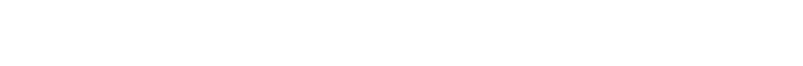

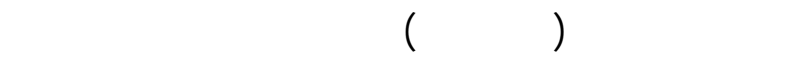

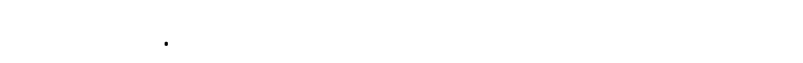

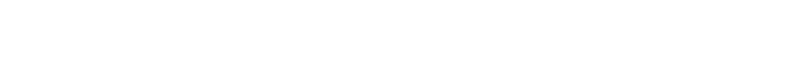

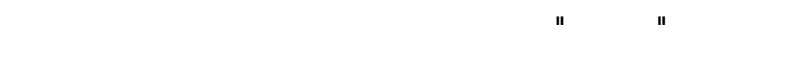

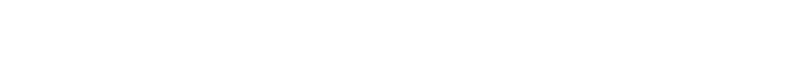

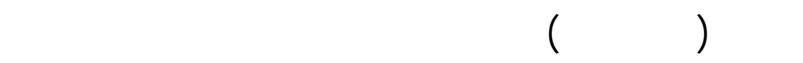

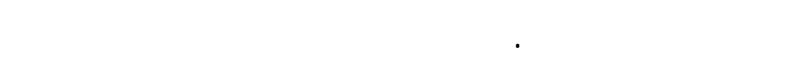
الاصلاح الذى فرضه قلاوون لم يستمرطويلا. والكم ـلم

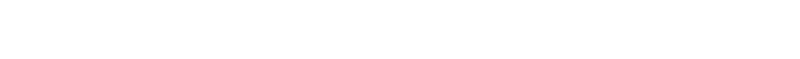

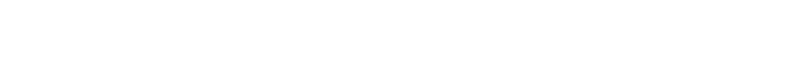
تتنهي عند الرسغ بشنيت متعدة ومع ذلك كلن من المألوف وفئ

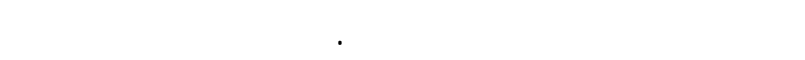

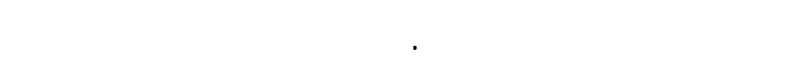

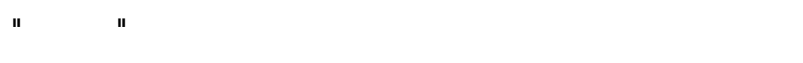
هطرزة الى زركث وذلك بدلامن تلك المصنوعة من الجوخ

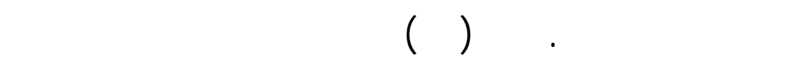
الامراء الآخرين. وكلن من المألوف لن يرت دى الأم ـراء

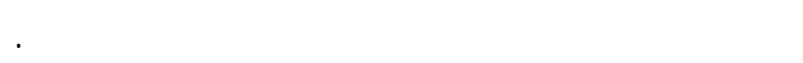
ولعله ما عرف بللسلارى (نت r I ) وكلن المراء الطقة الرفيعة يزخرفون لمملمها باللثرطة المطرزة. ويزينونها بالفراء غاله الثن. ويحثنا

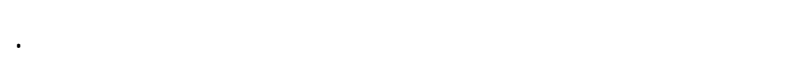
ويشد حول المعطف حزلم فتط. ويلبس للسف اله الجانب
قلاوون ابطل لبس الكم الضيق وان البنه الملك الاشرف خليل اعلى لخاصكيته ولمماليكة الاقبية الطلس

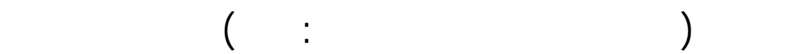
كان اللطلان يلبس تمت ملابسه زرية. وقد وصفت على النها زردية داودية عبارة عن قميص من الزرد له شهرة صناعية كلن يضعه السطلان تهت ملابسه لتوفير لسبب

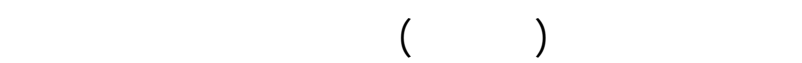
للسلطان حزه " بند" عبارة عنشريط من الحرير الاصفر (ع،صعץ\%) وللسطلن هو صلمب الحق الوحيد في منح الاحزمة اله الامراء الظلم كجزء من ثيلب التثريف ومن ولهو المألوف لن ترصع بالاحجار الكريمة .

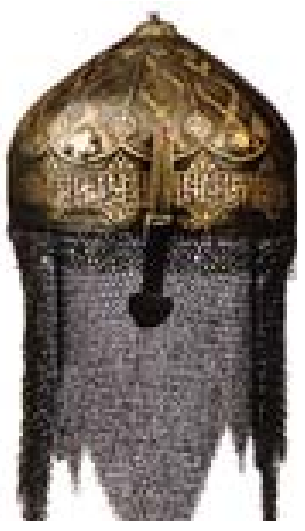

شكل ا ـ خونة مملوكية، من الزرد لحملية العنق وهـم

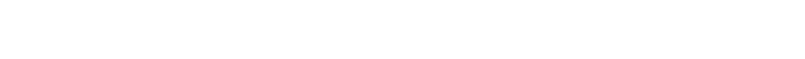
هى هالل ازبأؤه الشناء الحملات العسكرية كلن السطلان يرتند اثناء الحملات العسكرية فنس الزى

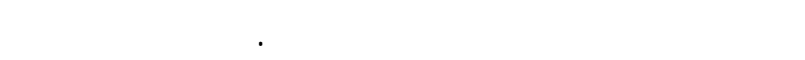
ان يرتدى اللسطلن درعا او يرتدى ملابسه المعتاة الثناء

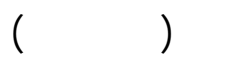
زى امراء المماليك

يرتدون فوق القميص واللبلس الاقبيية التترية ومن فوقها التكلاوت. وصف المقريزى التكلاوات على النها ضرب من اللبلس يرتدى فى الهند وفى مصر من قب لـ الام _راء (سا، 
سيلار نائب للسطنة في عصر محمد بن قلاوون وبيبرس الساس

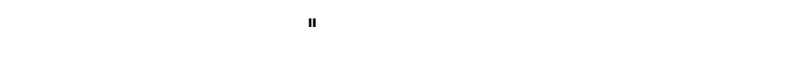

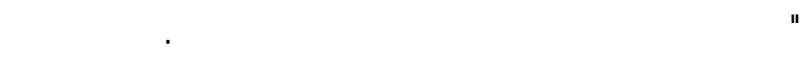

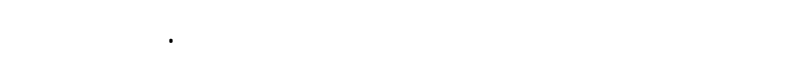

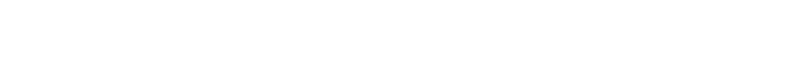

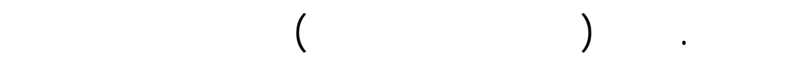
الطلسى المديف وكلفت هنة الثيلب تزين بالجواهر واللآلئ،

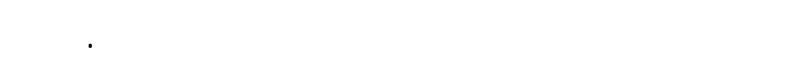

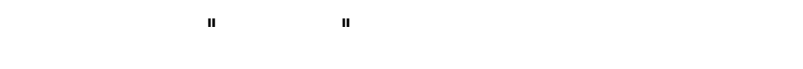
الإستعمل رفيع اللشهرة الثناء حكم الملك الناصر محمد وقد

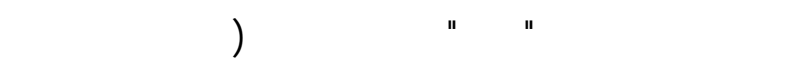

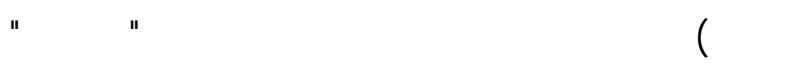

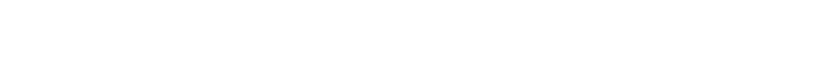

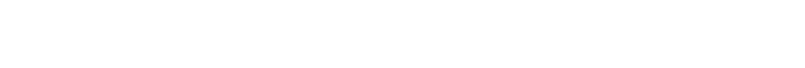

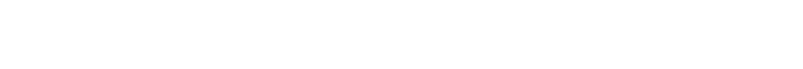

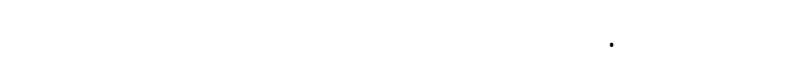

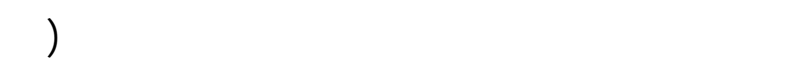

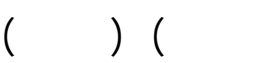

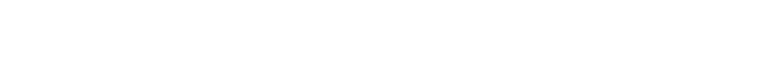
المملوكى اللثركسى المتلخر هـ "الملوطة "وجمعها ملاليط.

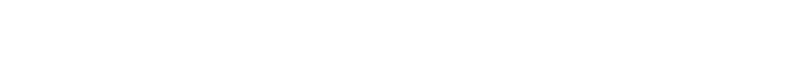

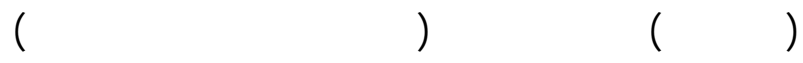

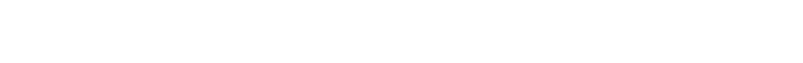

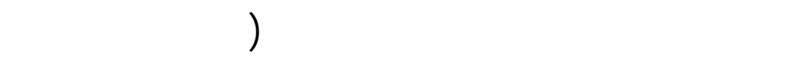
ص991) لما المماليك العاديون فكانوا يرتدون الثناء

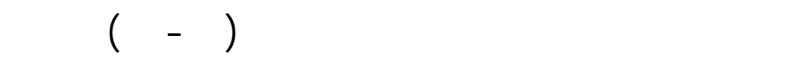

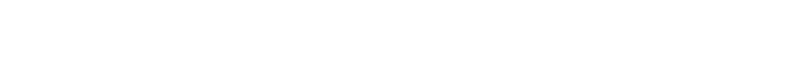
والملوطة. ورداء المالوطة كان يرتنيه غير العسكريين

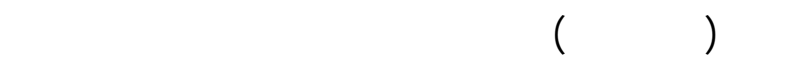

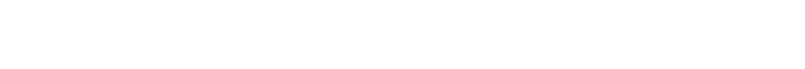
طلق عليها لمه جوخة (نت -r I ) وقد ورد عن المقريزي

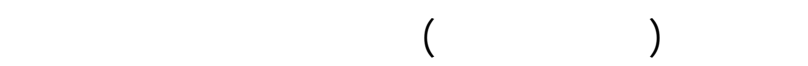

الايسر ويوضع كيس من الجلد طلق عليه لمبم "صووق" والكزلك معا على الجانب الايمن(ع، صبّاع)

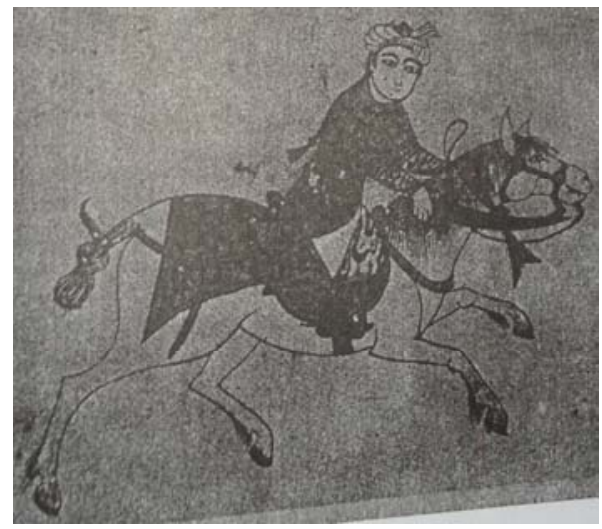

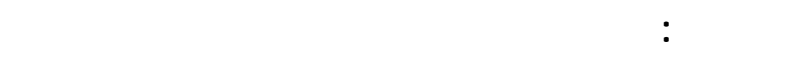
فاوس من الحوس السلالن يرتحكقباعن من الالالس زي يقدوا الجناد الحلفة واعيلن الجند لجناد الحلة هم جنود من الدرجة الثانية. كان عددهم غفير، وربما نظل فيهم من لبس بصفة الجند من المتعمين

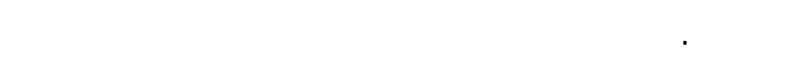

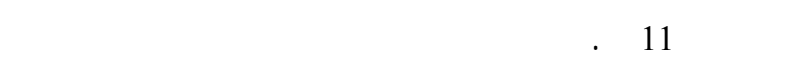

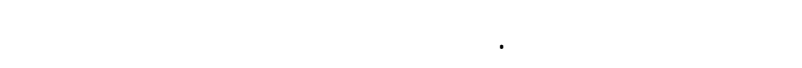
والمتعممن والعربان والعلمة(فت -11)

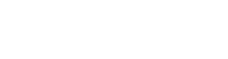

الزى عبارة عن القبية تترية وجمعها تتريك. وهو

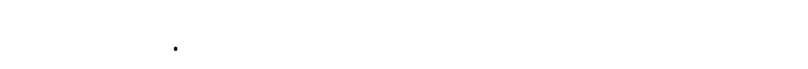

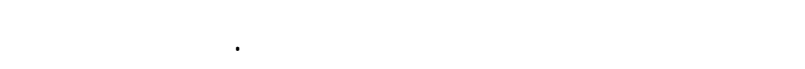
عبارة المقريزى الن التتريت كالفت مؤلفه من الحرية الحرير

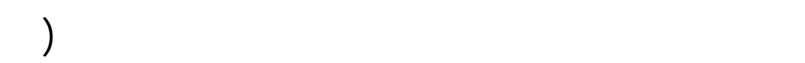

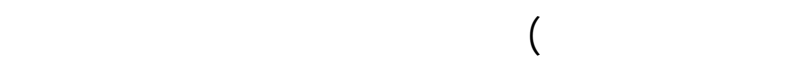
القباء ولكن لمملمها لكثر لتساعا من لمملم القباء التحتافي

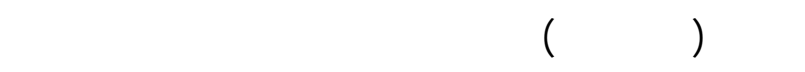

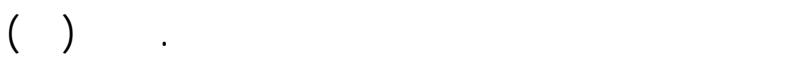

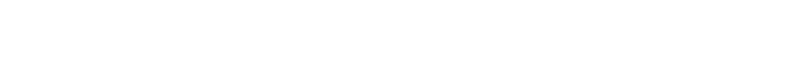
طلق عليه لمه "سيلارى اوسلارية". الذى انخله الامير 


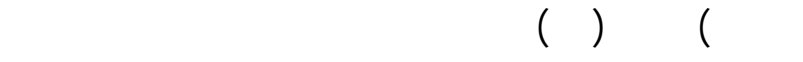
المماليك البرجية، وطل محله الطواقي ذات التالت الألوان

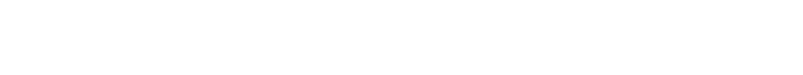
على ارتدائها على حد السواء ولكن بغير عملمة.

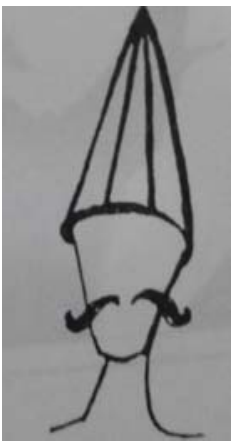

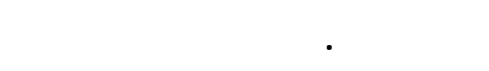

r rالكلوتة

لخف من اللثربوث العادى ولكنها لا تقل عنه مكانة من

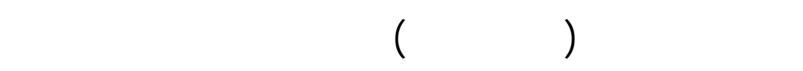
للمَّنقرطية العسكرية النين لطاق عليهم لمبم "المكلوتون"

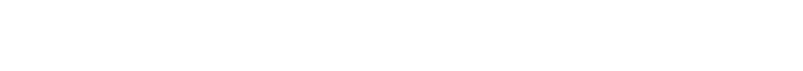

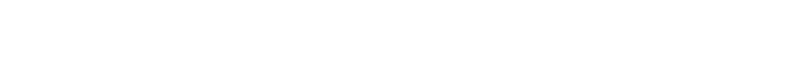

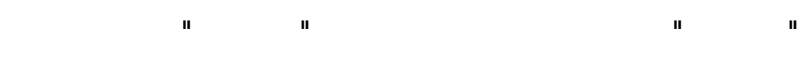

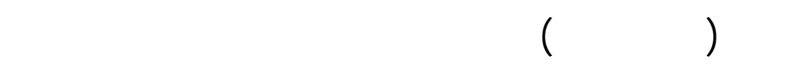
الكلوتة صغيرة الحجم وتصنع عادة من الصوف المطلى المعلى

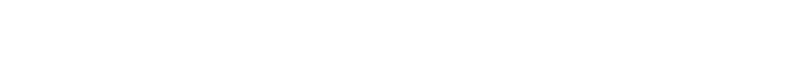
حولها منيل صغير. وفى عصر يلبغا الخاصكى نائب اللسطنة صارت الكلوتة والمنيل الذى يلف حولها لكبر

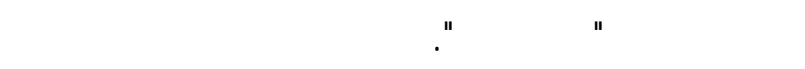

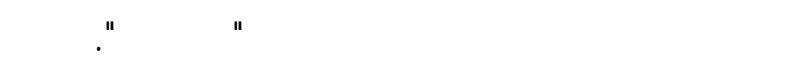

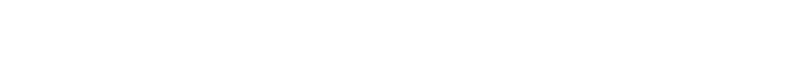

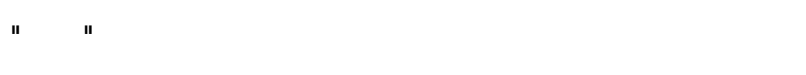

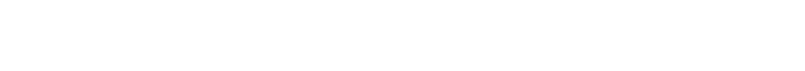

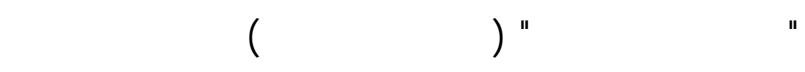

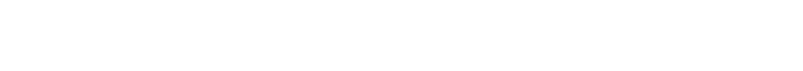
(ع، صعام) كما فسشكل (ع) () ).
الرفيعة بل كان للسطان فرج فنسه يرتنيها ليضا من حين لآخر(ع، صاع) وفى فصل الصيف كالت جمبع الملابس

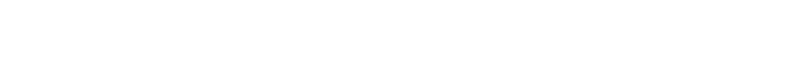
"نصالف" اوما يماثله من اقمشة لخرىى، وفى الشتاء تنكون الملابس ملونة من الصوف اوالحرير غالى الثمن مطنة الثنة بالفراء (نت - ا I ) اللحزمة

تعتبر الاحزمة من اهم الدلالات الطقية والدينية في العصر المملوكى فقد تعددت وتنوعت الشكالها والوالنها

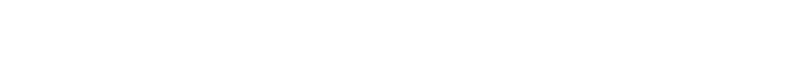

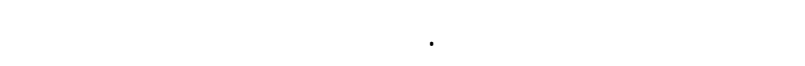

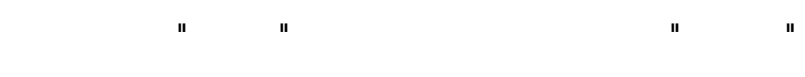

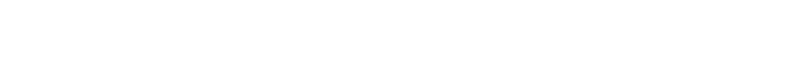

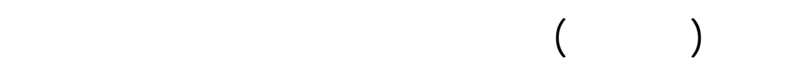

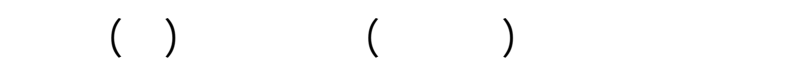

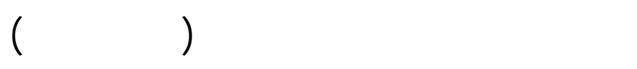

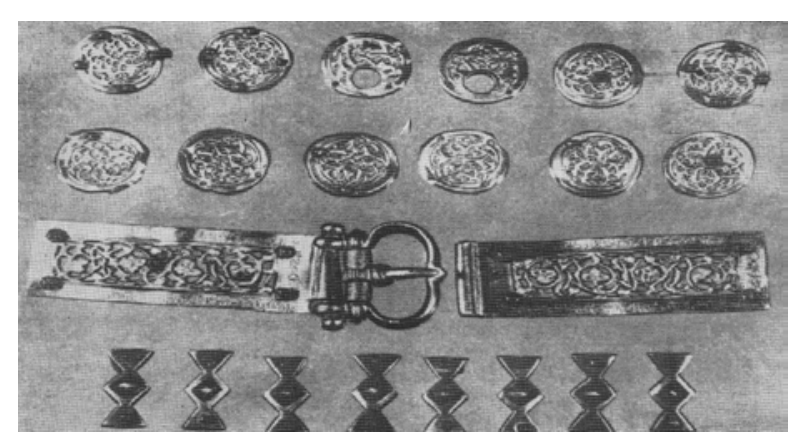

ششل rا: لوحة توضنح الجزاءمن حيامة المك الص Lالح

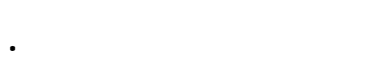
I - الشربوث

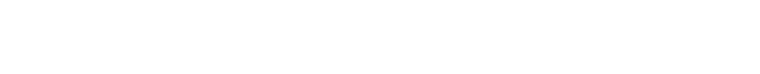

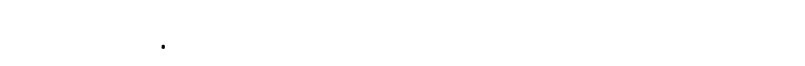

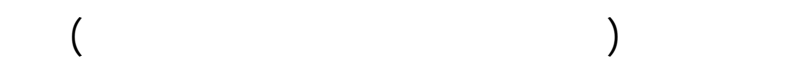

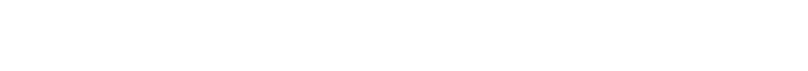

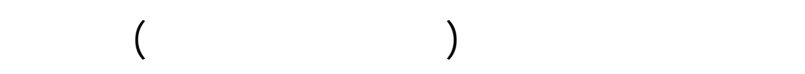

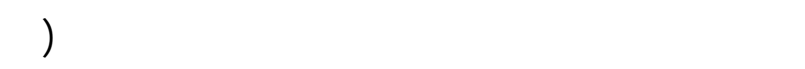


لبلس للرئس وجمعهاطوالقى. وتعف فى اللغة العربية

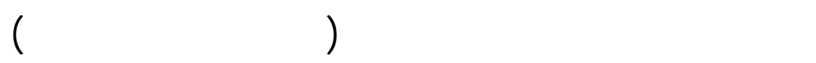
وكلت تشبه الكوفية النى يلبسها الصبيلن والبنات فلبسنها

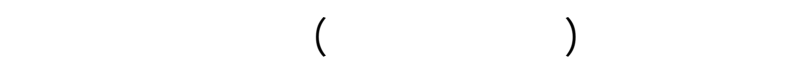

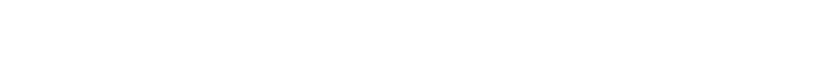
من الوان مختلفة وكلن ارفقاعها يبلغ سس فرس ذراع تقريبا

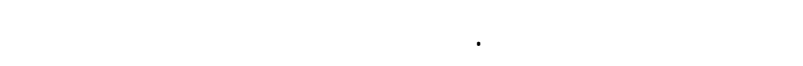

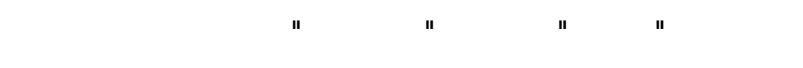
الارففاع ويبلغطولها حواله ثلثى ذراع، وعنئذ حدث تغير

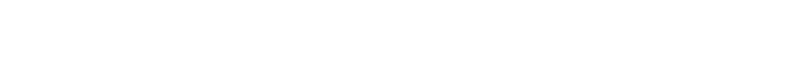

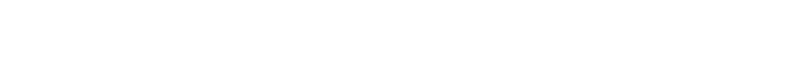

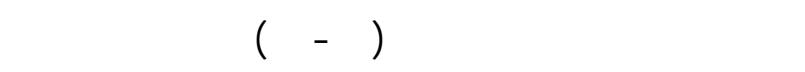

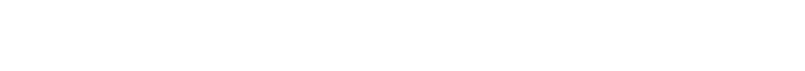

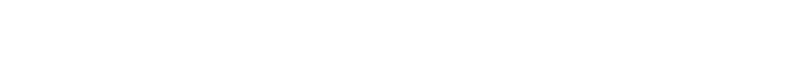

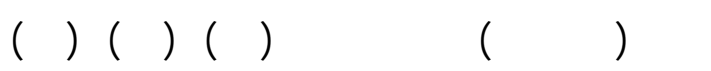

\section{ז- الزوط}

لبلس للرئس عبارة عن قملث يستعهل كغطاء للرئس.

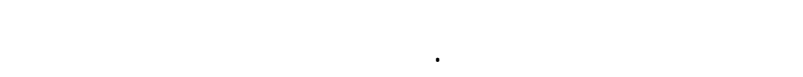
اللطقات الدنيا من اللثعب كما النه حرم على الفئن الفلاحنين

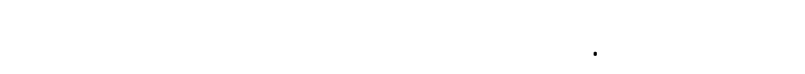

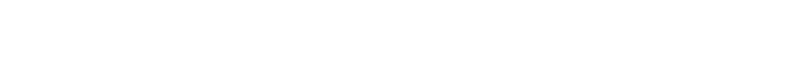

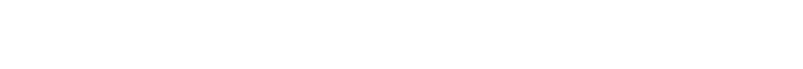

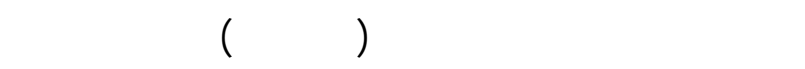

\section{لبلس الفعم لللقة العسكرية}

عبارة عن حذاء برقبة طويلة ططلق عليه لمام "خف".

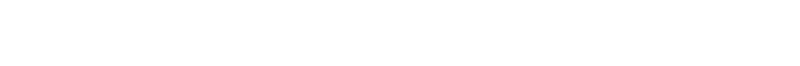

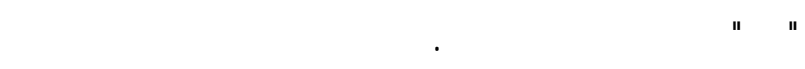

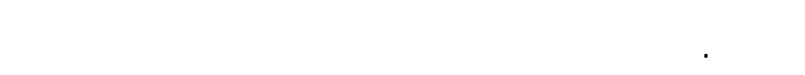

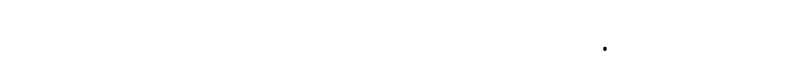
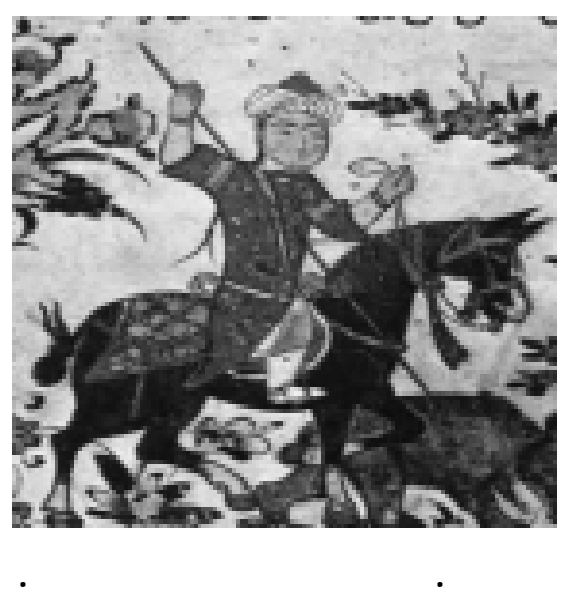

r - الممالمة الاميرية

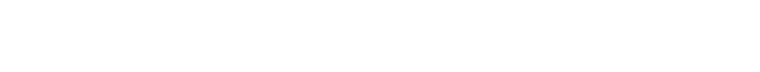
اللشكلن الرئيسن لهما هما "التخفية الصغيرة والتخفيفة

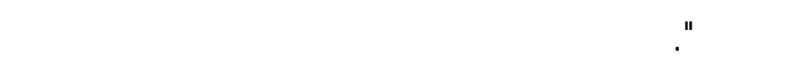

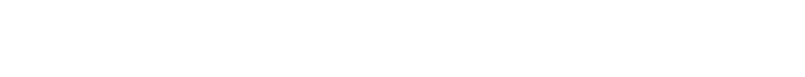

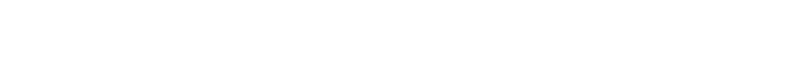

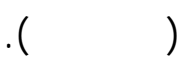

\section{ع - اللسرفوج}

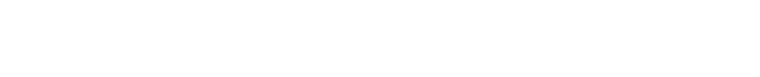
"ستراقوج" وكلن يشبه اله حد كبير الزى التترى المميز.

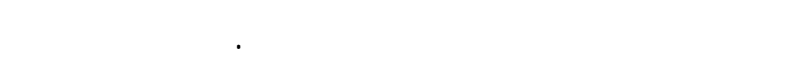

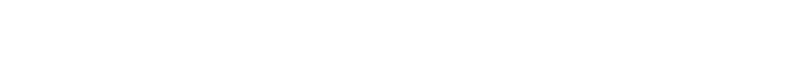

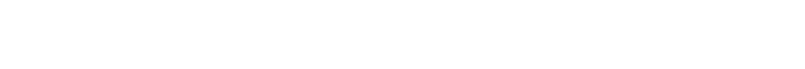
جعل جولسيسه غير متميزين عن التتر. فللسراقوج عبارة

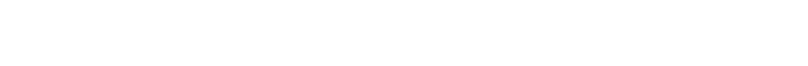

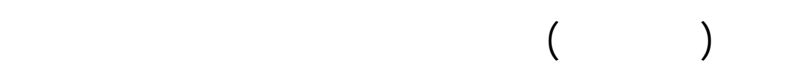

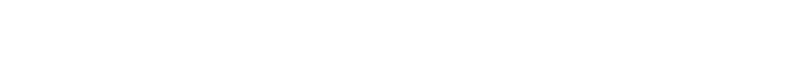
عاد الى الظهور فى عصر المماليك للثرلمسة كلبلس رلأس الس

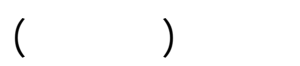




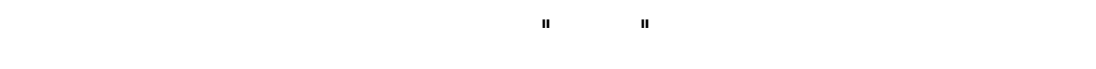

الخاصكية هم أقرب المماليك للسطانية على اللسطان. (7) (1) (1) (1) وهم الحرس الشخصي للسطان. وكانوا يسوقون المحل

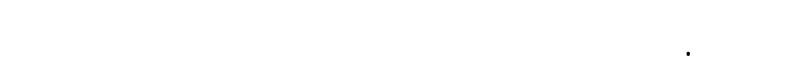

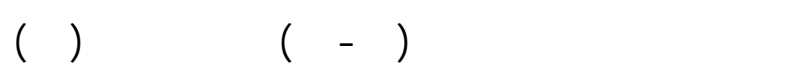

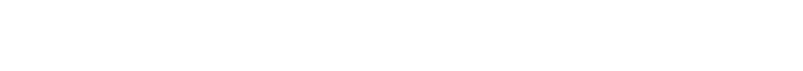

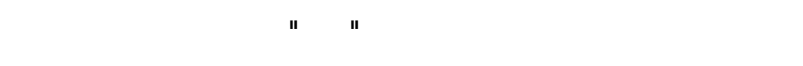

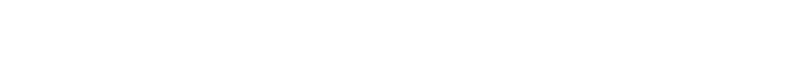

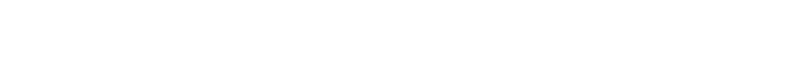

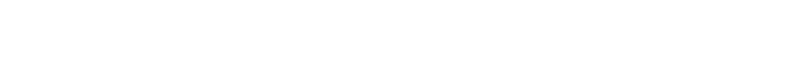
الجيش وما يماثلهم فى المرتبة من المراء.

وكلن من المعتاد ارتداء حذاء فوق الخف يطلق عليه

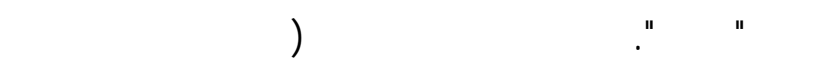

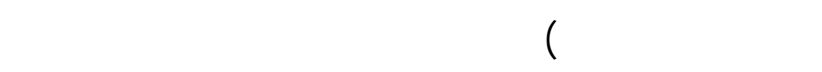

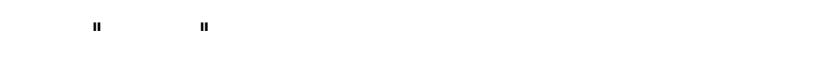

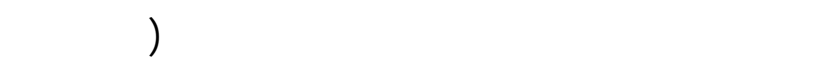

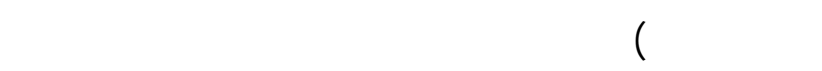

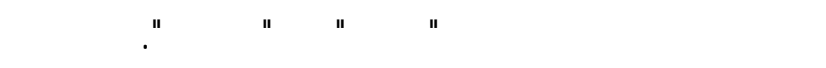

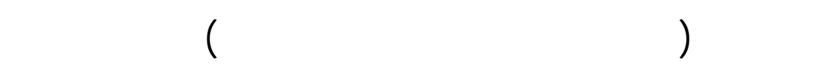
يصنع من الجلد المرلمثه لحمر اللونسميك مدبب والموفيها

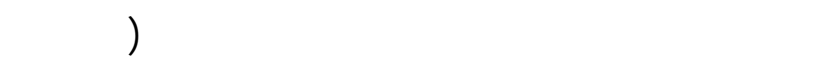
(er
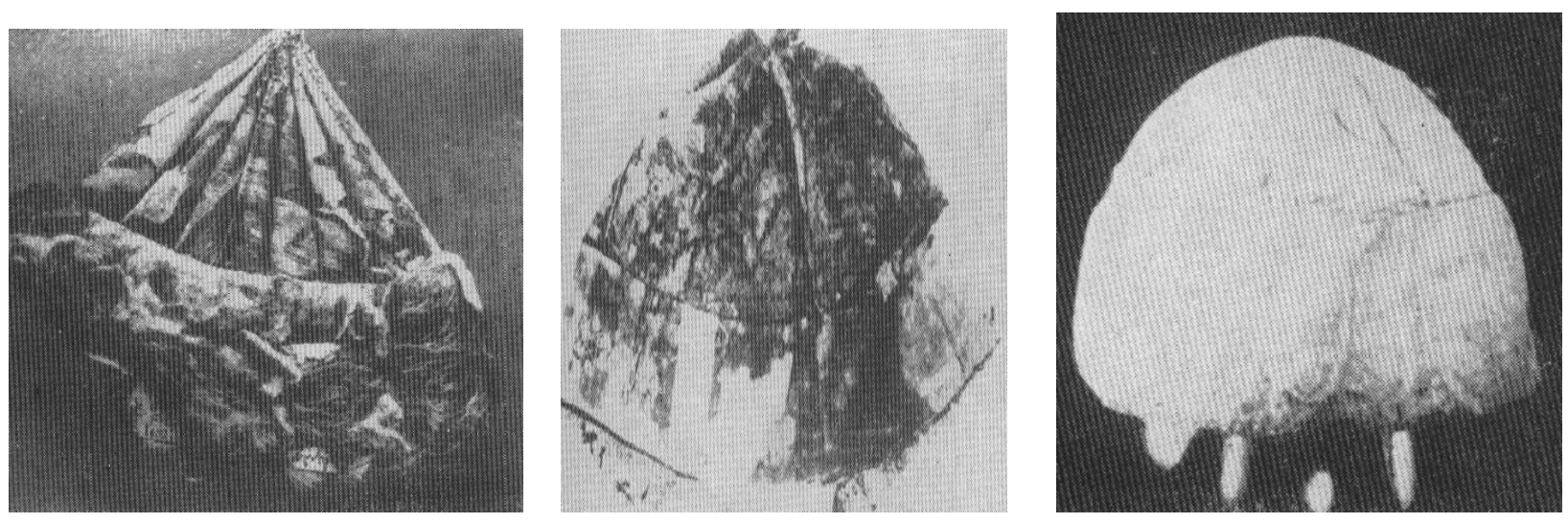

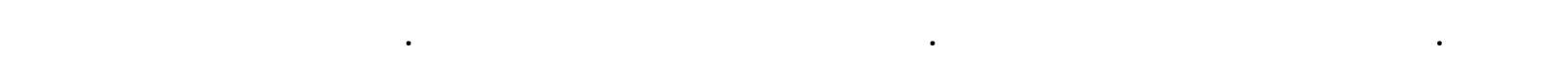

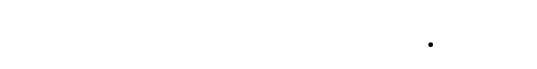

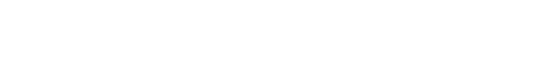

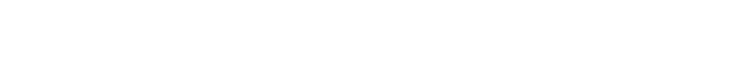
والبرت. اللن الاسلاف

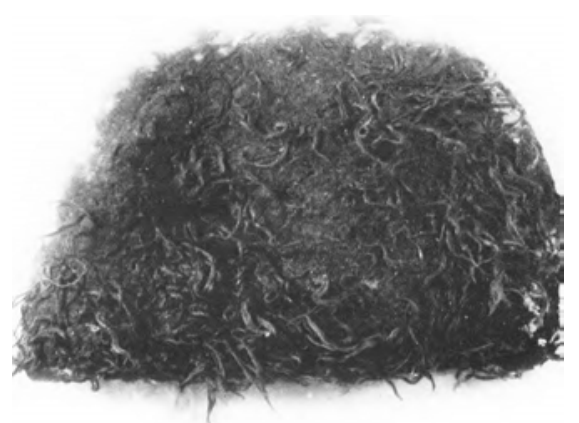

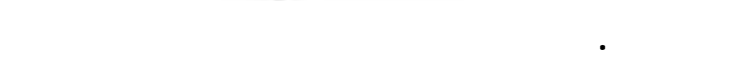




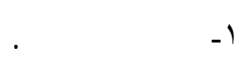

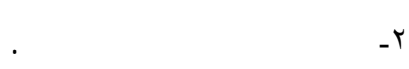

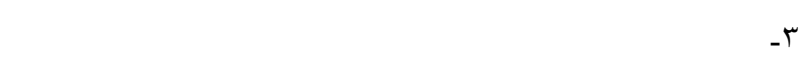

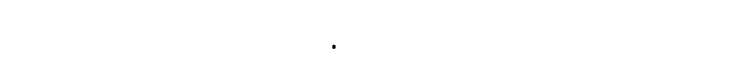

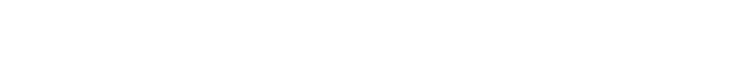

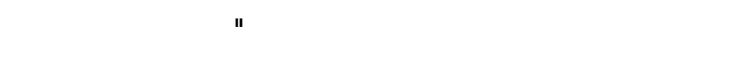

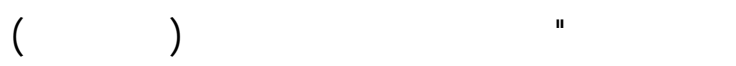

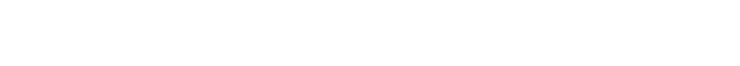

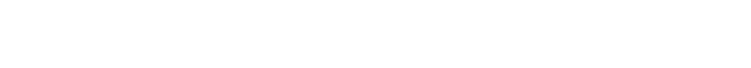

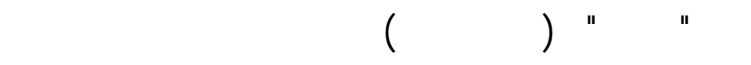
سترة قصيرة لا يزيدطولها عن لالم مصنوعة من قملث تيندا ولها لكملم طويلة وياقة عريضة وهيد

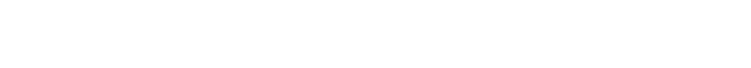

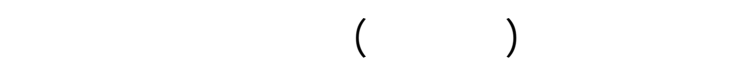
عثر كلن يطلق على البريجاندين لهم "قرقل" ويتضح هذا من التعريف الذى قدة القفتشنى الن الدرع والقرقل يصنع من صفائح الحيد المغثى بالديباج

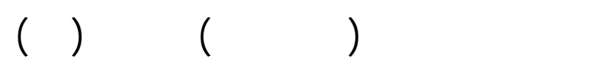

\section{زى الفضاة والهاماء}

ارتدت الهيئة العليا السمية من رجل الين والوزراء

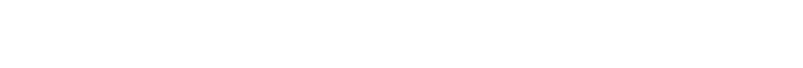

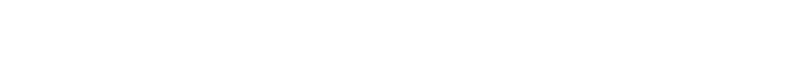

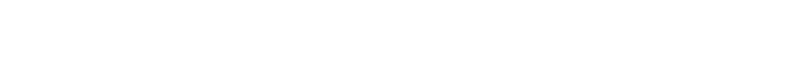

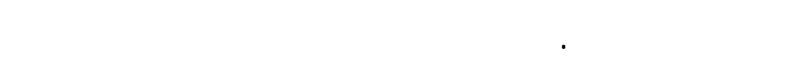

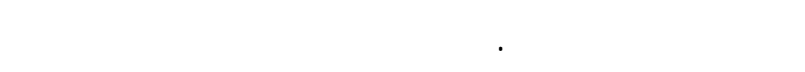

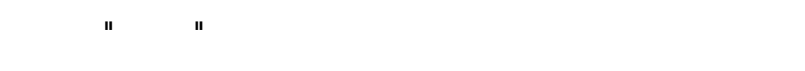

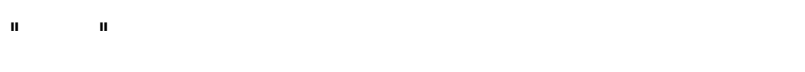

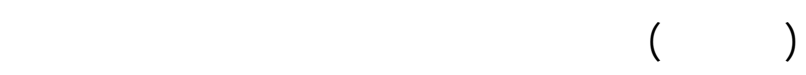

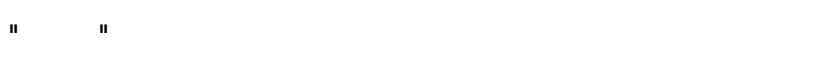
تستسل بين الكقين حت تبلغ "قربوس"سروبهوه.
والبند عبارة عن شريط ياف حول الويط ويعقد من الامل ويتله طرفه حتق الركبة وقد يكون البند عريضا

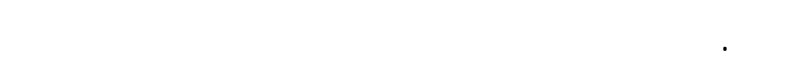

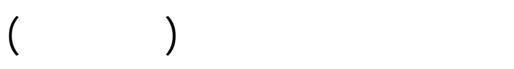

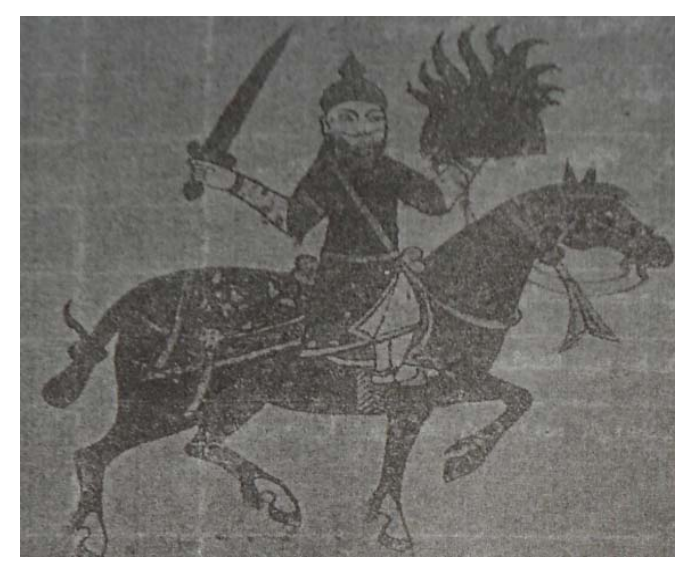

شأل 19 ـ لوحة الفنل على - تهود الل الهصر الممل وكك

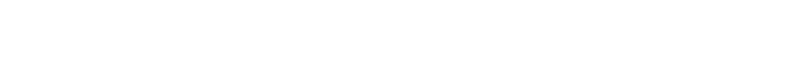

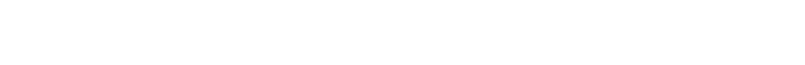
"التخفيفة الكبيرة" وظهر الغباعين والمهماز زى الغاس فهو ضيق وقصير ذو لكملمطويلة ضيقة حتى يساعد الفاس على اداء مهمته وله فتحة رقبة مستيرة ويحتوى

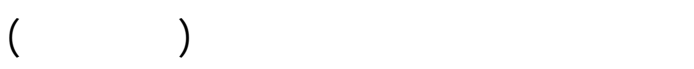
ازباء الجند عبارة عن قميص محبك الجم ويصل اللى ما تحت الركبة. وقد لستخدم العرب الدرع حت قل الإلام وكلن

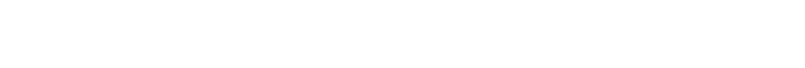

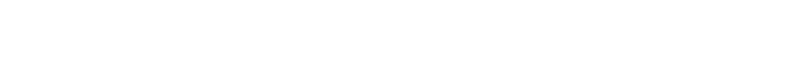

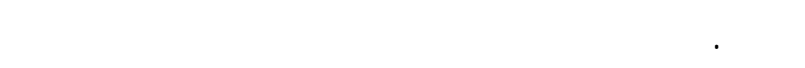

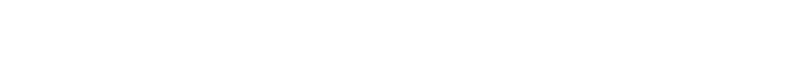
البريجاننينات وهـ قمصل من الجلد مثبت بها حلقلت ورقائق من الزرد او الصلب ويوجد ثلاثة النواع من الدروع 

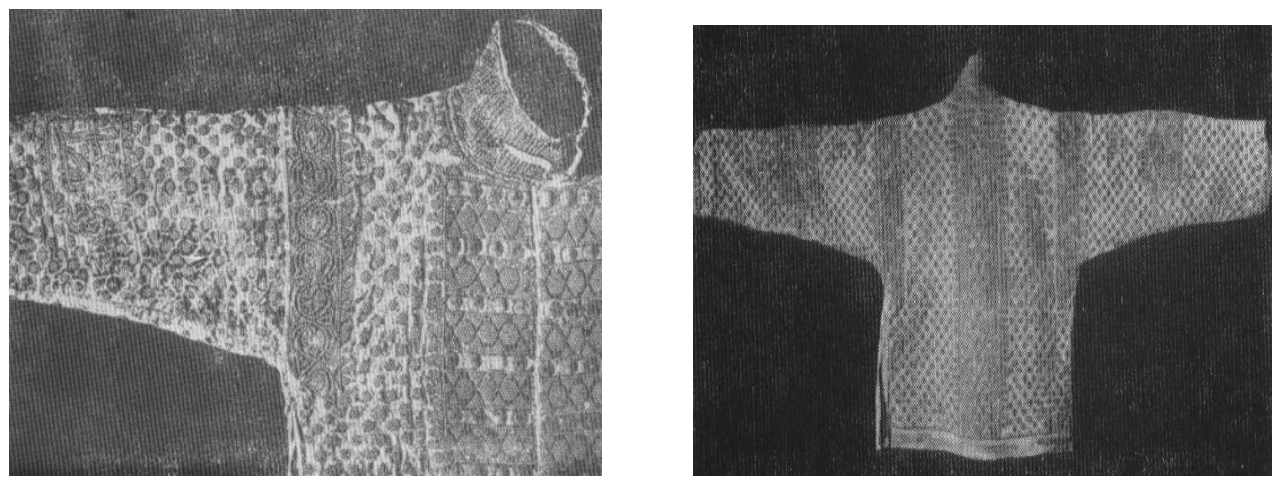

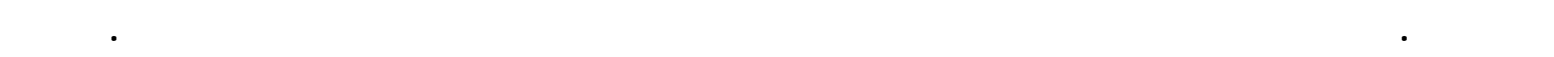

\section{المملوك مجفوظ بالمتف الانل بفلورنسا.}

الكف ولبس الغطباء دلقا مستدير الثكل لسود اللون،

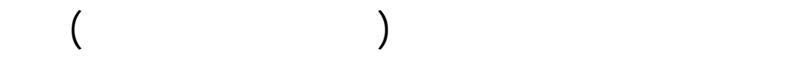

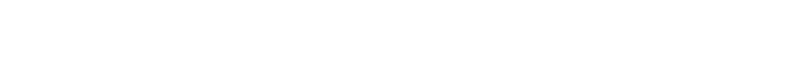
"فرجية" وقد وصفها لين فى (اف ليلة وليلة، جا، صعץّ، النص الانجليزى)|الفرجية ثوب فضفاض هونهاف يعل من الجوخ عاة، وله كمان ولسعانطويلان يتجاوزان قليلا لطرف الاصاع وهذان الكملن بغير قريج البتة. ويلبس هذا الثوب خاصة افرادطقة العلماء (سا، مج · ،

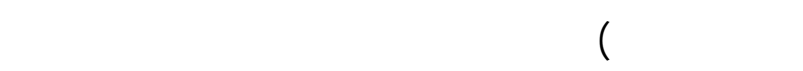
اقمشة متنوعة هسبما يتنلسب مع فصول للسنة من صوف فلف

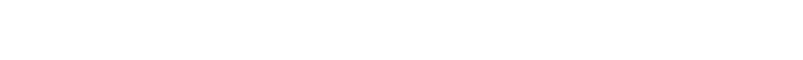
المملوكى كلن يوجد نوعلن من الفرجية الفوقانية والتحتانية. لما الفوقانية فهى الفرجية الاصلية ويلق عليها لحيانا لمام

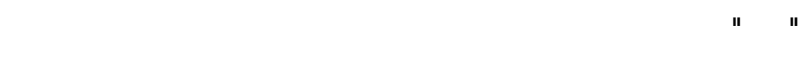

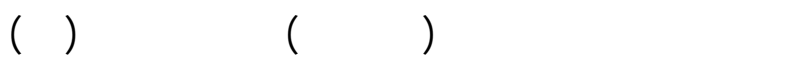
وجرت العادة لن يرتدى العلماء فى اللثتاء ملابس من

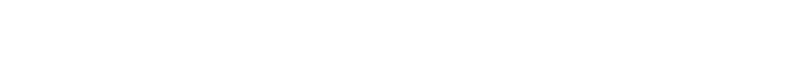

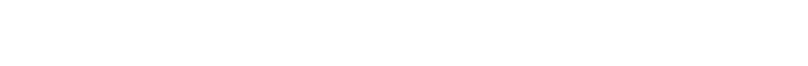

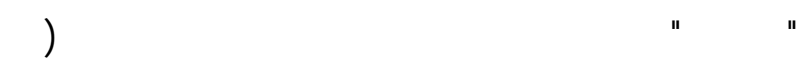

(9) ص
لما القيار عبارة عن غطاء للارلس خاص بالقضاة والنبلاء وكلن يصنع من قملث لسكندرالف رفيع فلخر يطلق عليه

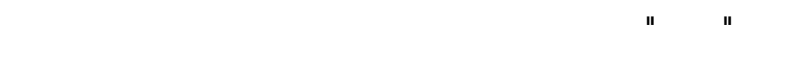

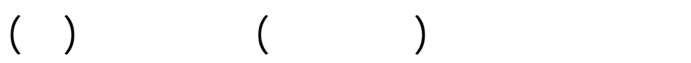

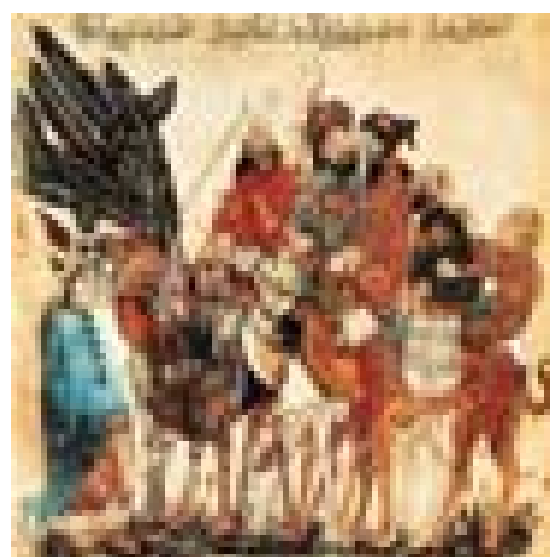

ششك اr: لوحةمن شقاملت الحربرى تمل قلفلة وقلهر فيهامجموعة مختافة من الالبسة الرئس الممامةمخلمالة "الإيار" الهمامة اللموبلة -قلنسوة قباء.

وارتدى المشابخ "الدق" فوق ملابسه بلكملم ولسعة وهو مفتوح فوق الكتلف بغير فتحة خلفية الى من غير بلابر

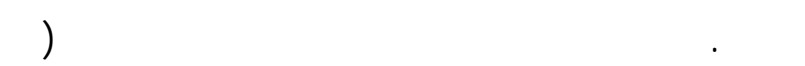
صوץ I) وهو كلمة فاسية الاصل. ويرى للسيوطى فى

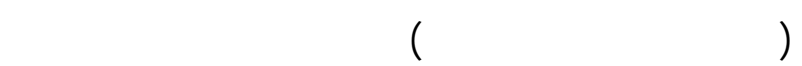
يرتدون دلقا ولسعا لم يكن مثقوقا لبل كالت فتحته من فوق 
وفى الايلم المهرة جرت العادة لن يرتدى رجل الدين من

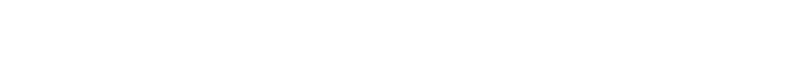

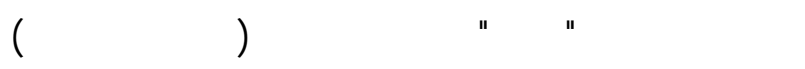
ومن الملابس التى تميز زى الطقة الرفيعة من رجل الدين

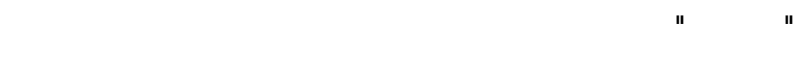

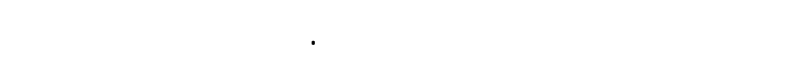

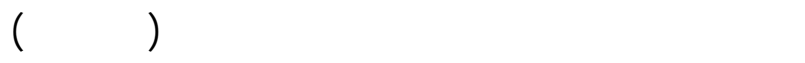
لما الطيلسلن ومن خلال توصف المؤرخين والرحالة له

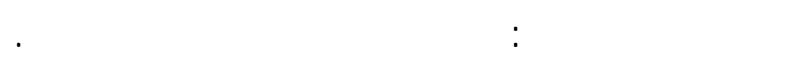
ووجد فى العصر المملوكى نوعلن من الطيلسلن فيثار

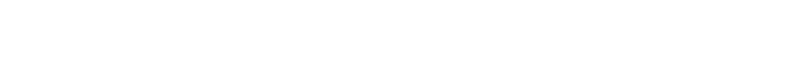
فى الوسط وذك لمرور الرئس منها، ولُحيانا لخرى يشار

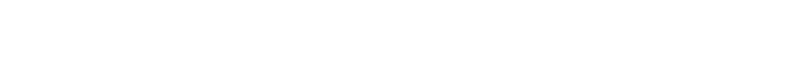

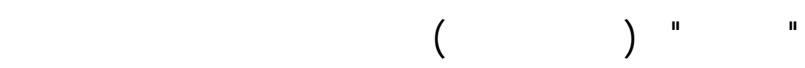
المقصوص بالطيلسلن الا النه من المحتقل النه لم يكن يلبس وبن كحلة القدلس على الصدر وفوق الظهر بل كالن يلبس المانس كاطرحة فوق العملمة وهو لحدى الملابس القليلة فى العام

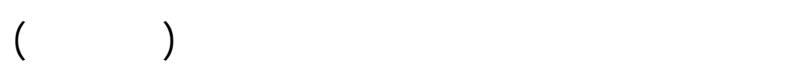
وكلن الطيلسن من ملابس للسلطين والقضالة وكلن اليضا

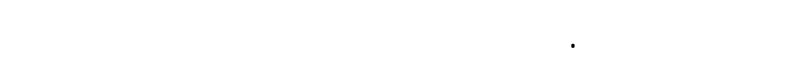

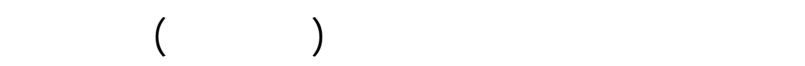

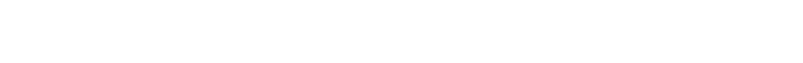

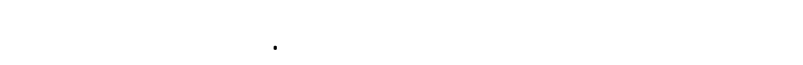
عباءة سوداء لها طرطور منلبب يوضع فوق عملمة

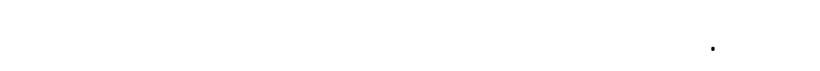

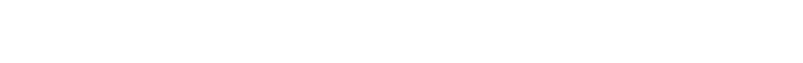

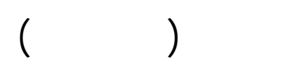

\section{زى السادة الششره}

كلن لسلالة النب(صلى) مكانة مرموقة دائما فى

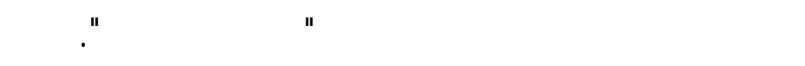

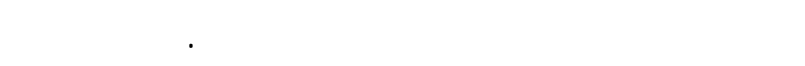

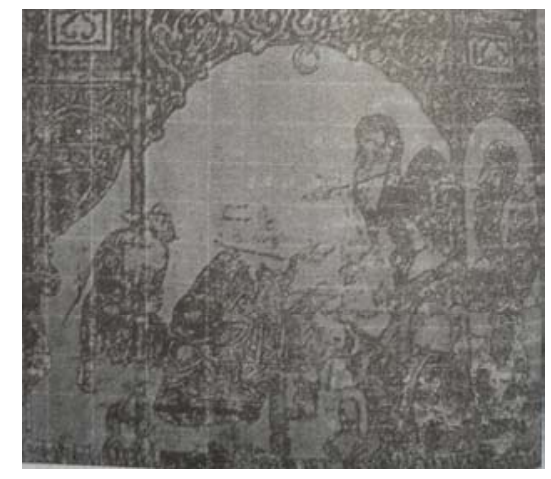

شكل بr: لوحةمن سقالت الحربرى تنهود الل علم

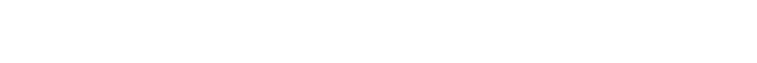
لينفراد -مجلس قضاء يأهرفيها الغاضفمرنديا اللارحة ازباء رجل السن قصد طائقة رجل الدن العلماء والمسلمين من غير الطقة العسكرية. وهم طبقة تتميز بلبس "العملمة" ظعرا

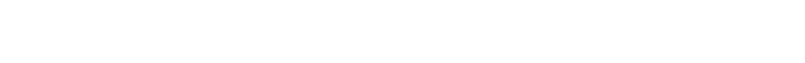
"اربب العمائم او المتعمون". بسبب كبر عمائمهُ، وانها

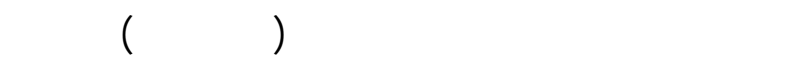
اهمية العملمة عن بقية الملابس الأخرى عند الحيث عن الهن

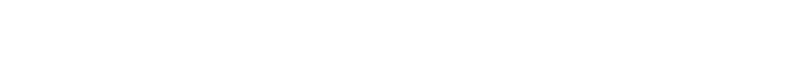

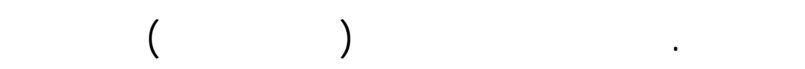
النمة بالثلم النصارى الازرق واليهود الاصفر وللسلمرة

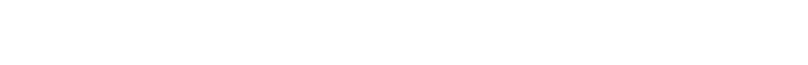
من الملبس. ومع مر العصور ازدادت العملمة كبرا

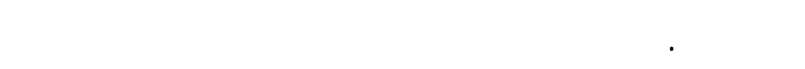

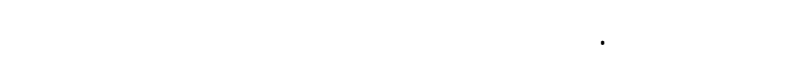
القملث وكلن يلبس تحت العملمةطقية صغيرة طلق عليها

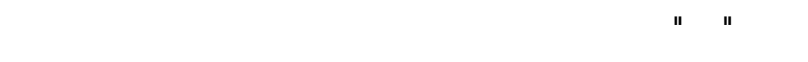
الطقية دون لستعمل ایىشع لخر معها (ع، ص • و) كما جرت العادة لن تصنع الطاقية المحبوكة تتحت العملمة من قملث رخيص، بينما وجد نوع مختلف من الحرير او من

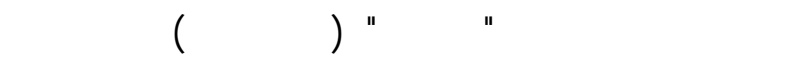
رجل الدين والعسكريين على للسواء عباءة خشنة كانت في

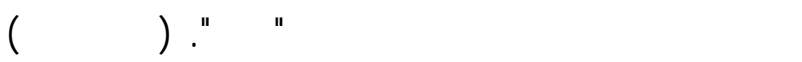




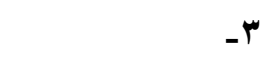

لمستعطل الرجل الازار او المئزر كلبلس خارجه

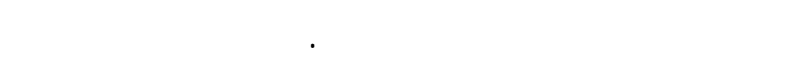

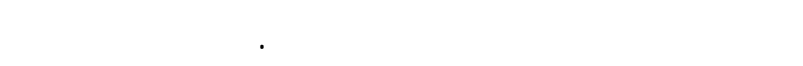
الازار علىستر العورة فعسب، بل وجد في بعض العبل الحيان

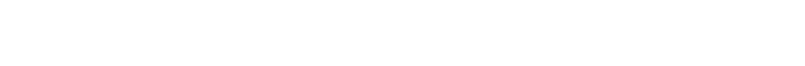

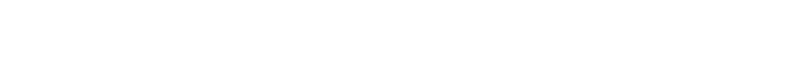

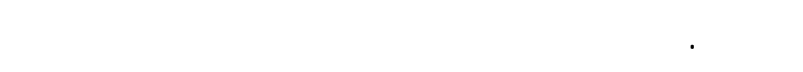

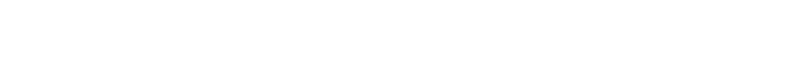

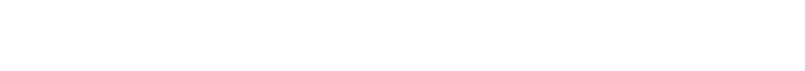

(r)

زى النساء من اهل السلطين والامراء تكاد المعلوملت كن ملابس النساء قليلة جدا. فملابس النساء لم تكن ازياؤها

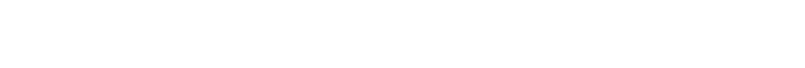

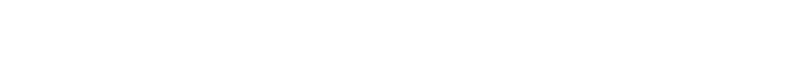
والخارجية ذات طراز حديث بمختلف الالوان حتى تنلسب الطقة النى تنتهى اليها وذك عكس نساء علمة اللثعب النى

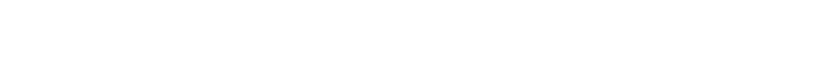

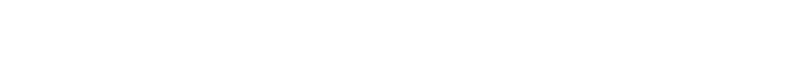

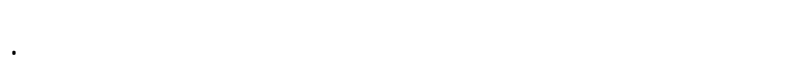

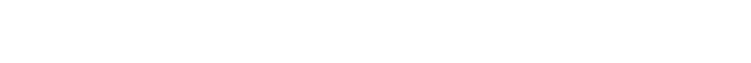
النساء في تاك الفترة بالغن في سعة القمصان حق كان فئن

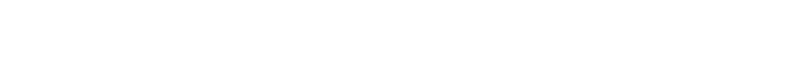

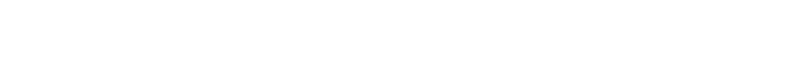

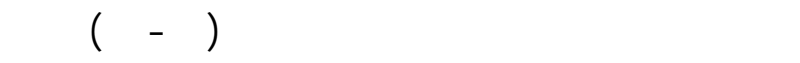

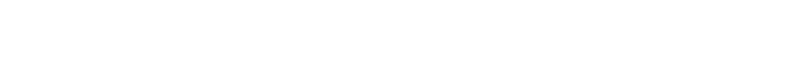

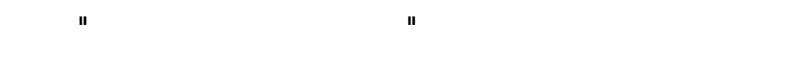

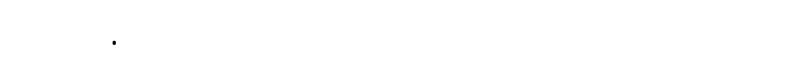
القميص الذى ينبغ ان يكون طويلاطقا للاحكلم الدينية

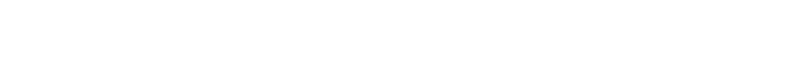

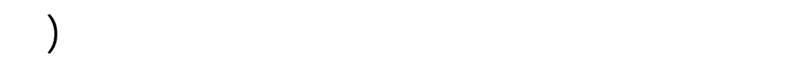

خاصة يشتون لكثرمن قطعة صغيرة خضراء فى عمائمهم. حق يمتازوا عن غيرهم تتظيما لقدرهم.

\section{الملابس الداخلية اللرجل}

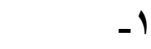

ارتنى رجل وأمراء المماليك قميصا تحت ملابسهر يلق عليه تحتانية، وعادة ما يصنع من الكتلن أو التطن، ويطل طوله إلى للساق، وله ألممل ولسعة يطل إلى إلى

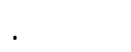

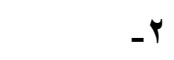

يوجد نوعين من اللسرول. النوع الاول عبارة عن

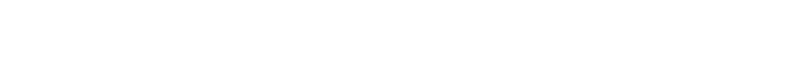

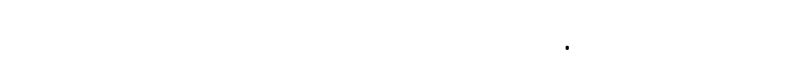
الركبة ولحيانا يضل اله نهاية للسقاق ولحيانا يكون فضفاضا وطويلا. اما الاقمشة التى صنهت منها فانها رخيصة وكلنت

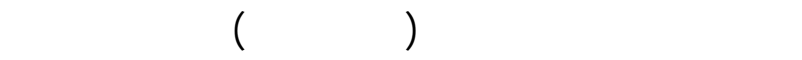
الاجزاء المهمة والمكملة للسرول. وهه عبارة عن حزلم من الحرير، وفى اغلب الاحيلن تكون مطرزة وموشية. ويستعملها الرجل والنساء على حد اللسواء لربط التبلن وللسرول الطويل حول مدار اللسرة (س، مجه9، جr، صع () والغرض من التكة هو تشبيت اللسرول على الونط (r)

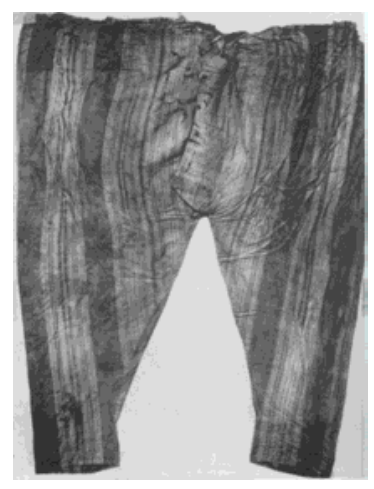

شكل سب:سرول من المصر الممل وك مصد نوع مـ ن

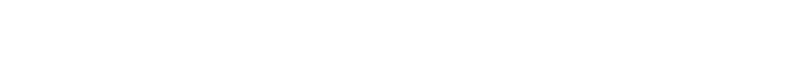
مجفظ بمتف السكالفتينير. 
الازارمن الملابس الخارجية الشائعة الق ارتتتها المرأة

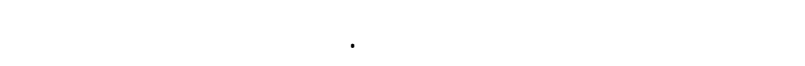

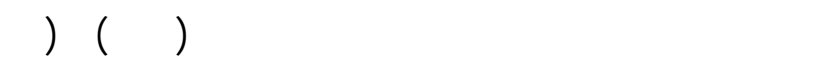

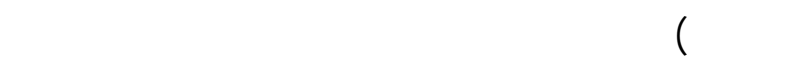
ذك لا يمكن للمرأة ان قطهر الا به، ومع ذلك لا باء يعتبر

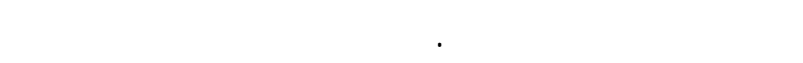

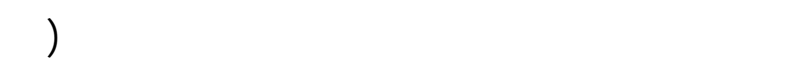

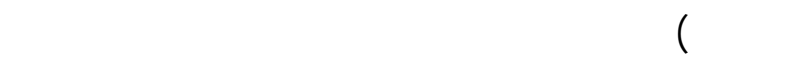

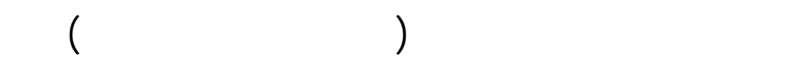

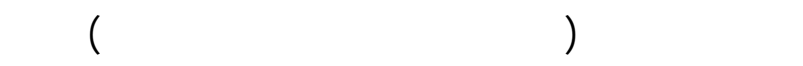

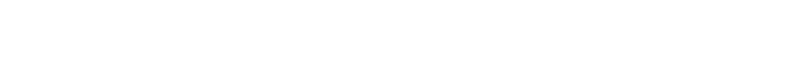

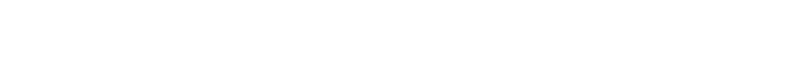

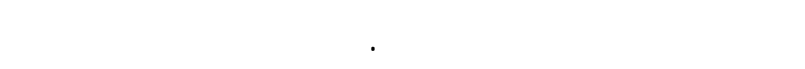

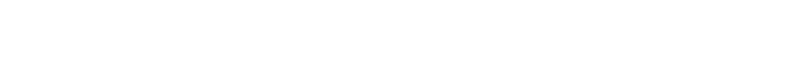

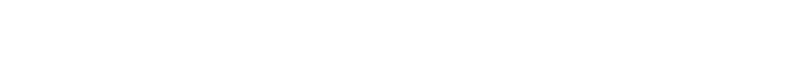

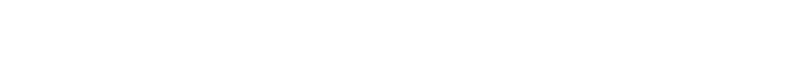

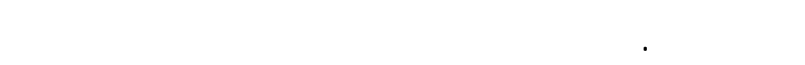
المرأة بنهايته بصورة تجعله يفاها من الجهة المالمالمية اليضا

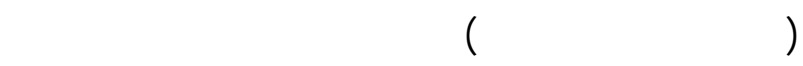

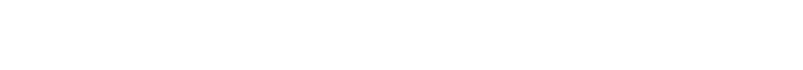

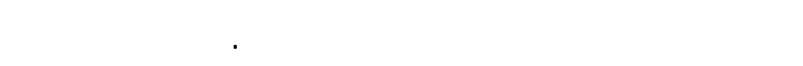

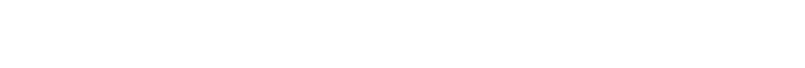

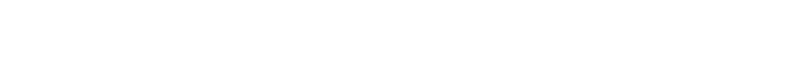

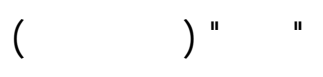

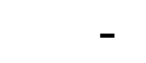
ارتنت المرأة نوعا من الملابس الولسعة عرفت بلبم

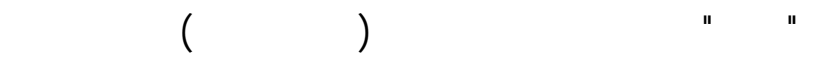

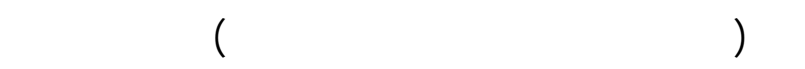
الملبوس الذى تثنير اليه كلمة سبلة، ومعف ذالك النه رداء ولسع فضفاض عرض رنيه يساوى على وجه القريب طول الجلبب فسه وهو مصنوع من الحرير ولونه لون ونه

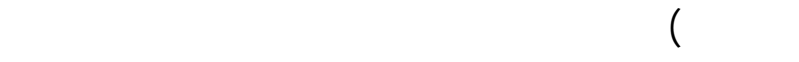

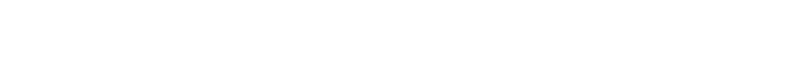

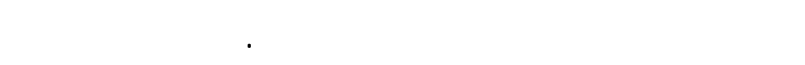

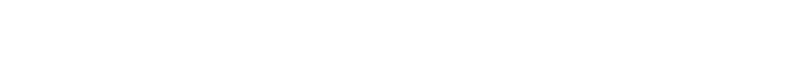

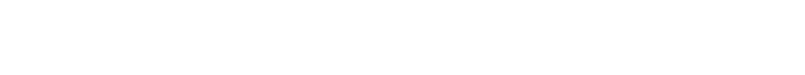

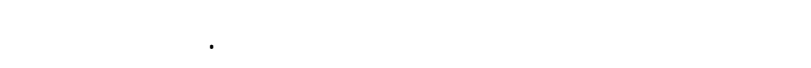

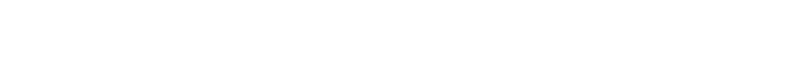

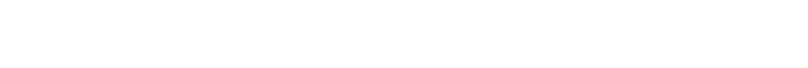

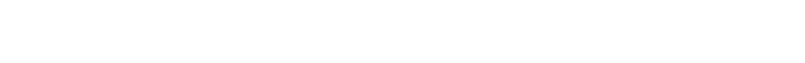
النساء بالرجل ومنعن من لبس العمائم الكبيرة ولبس الثيب المفتوحة الاقبية القصيرة (فت -بـاء) الازباء الخارجية للنساء الاءبة

كلت ملابس النساء فى جمبع المن متشابهه من حيث شكلها العلم وهـ عبارة عن I - قميص ولسع طويل تصل لطارافه اله الارض ون وله

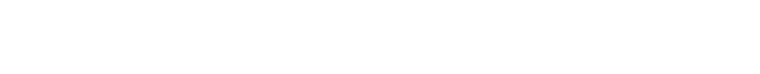
ترتدىسبلة او ازارا يعلو ملابسها ويظطى جمبع بدنها.

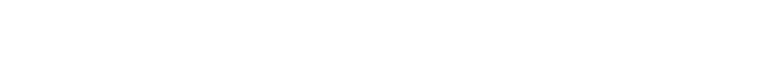
كن يرتنين ثيلبطويلة تسمب انيالها على الارض ولها

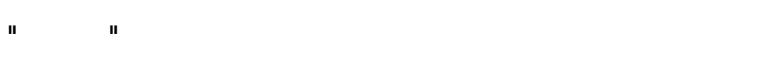

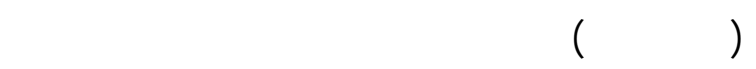

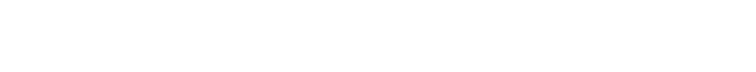

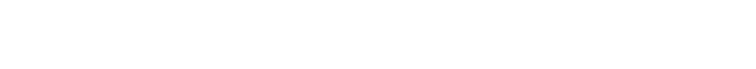

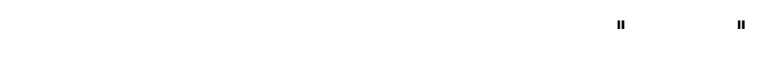
لكثر المثلة القى تبعث على الدهشة البالغة فى التبذير

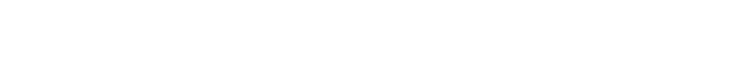

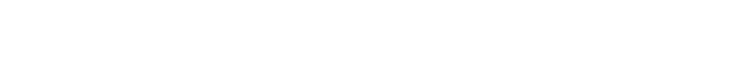

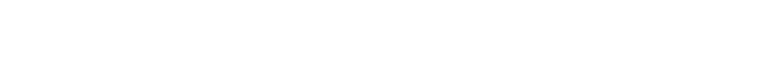

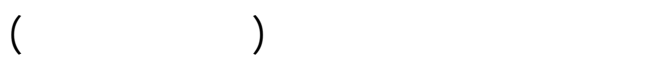


من الملابس الخارجية الق ارتتتها النساء. وجاء فى

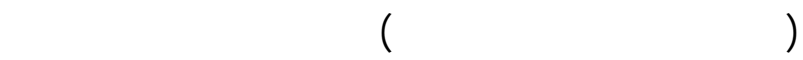
القملث التطنى المخطط بخطوط زرقاء وبيضاء. وطولها

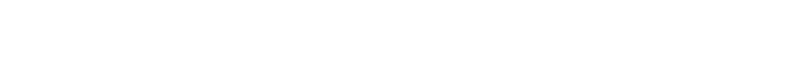

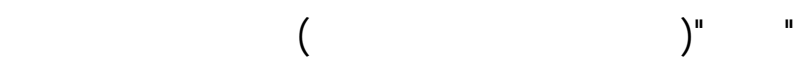
جميعها بملاءة فضفاضة عرفت بلسماء متعددة منها المرط

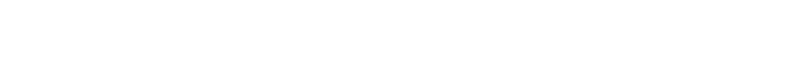

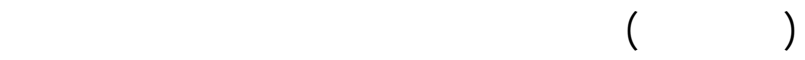

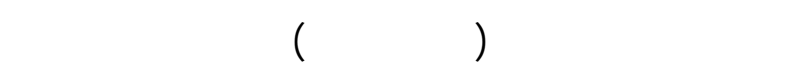

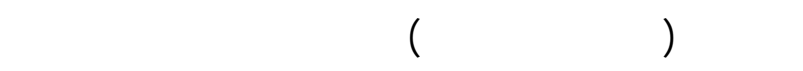

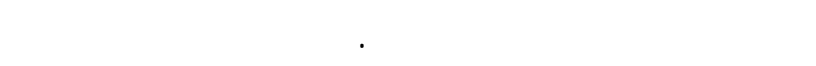

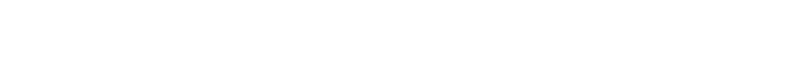

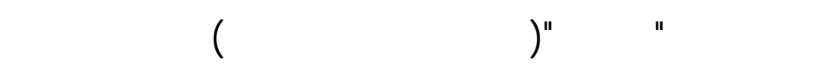
سبقشرحه.

\section{اغلية الرئس}

من اغطية الرلس المستخدمة لدى النساء "الطرحة"

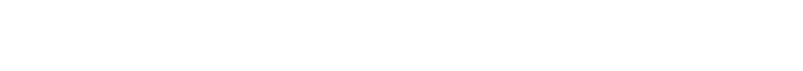

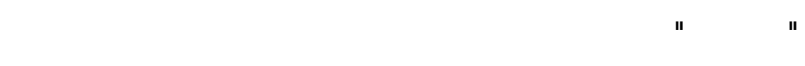
الشعر ومن المحتقل النها تشبة فى هيئتها الق ترتيها

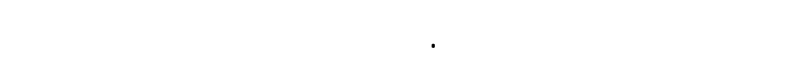

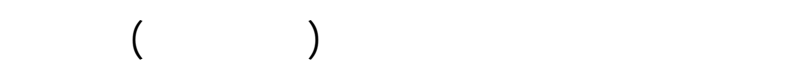

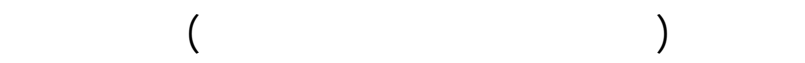
تشير الهطرحة من الحريرمربعة الشكلسوداء اللون، لها

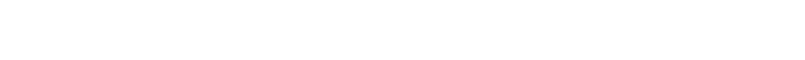
بها الرلأس، وتتله من الخلف كقة وحيدة (نت -9)

\section{الممالة النسلئة}

عمائم النساء كانت مسار قدد وجلششيد الا ان الطريقة العنيفة الت هلجم بها رجل الدين النساء اللاتى يلبسن العمائم. وفىسنة r77هـ ـ صدر مسروم يحرم على النساء

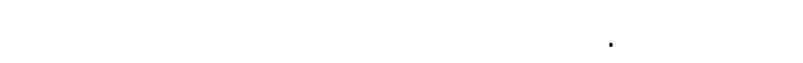

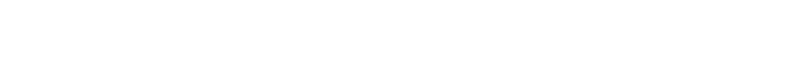

القرنل فى مظم الحول او لونه وردى او بفنجى. وترتدى النساء هذا الرداء حين يردن مغادرة منازلهي.

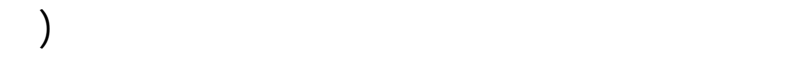

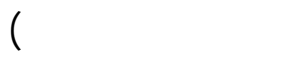

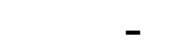

لستخدت كلمة جلبب مرادفا لكلمة ازار. وتشير اله الملحفة الهائلة التى يلتحف بها النساءمن الرلس الس الى القدمين

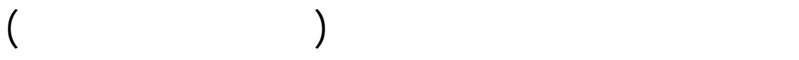
ويصنع الجلبل من منسوجلت تبعا للأحول التى تتنه اليها

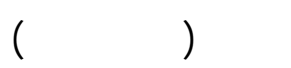

$$
0
$$

يظطى الجهم كله وله فتحة رقبة مستديرة وله كملن طويلين ولسعين اللى السغ. وهذا النوع كلن شائعا فى ولى

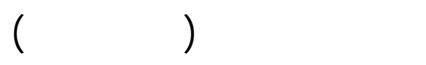

$$
\text { } 7 \text { - الزنار }
$$

نوع من النواع الاحزمة من ازياء اهل الذمة وقد فرضت

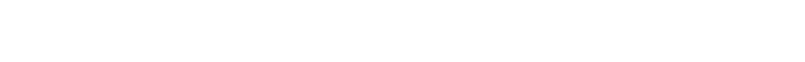
المرأة النمية وسطها بالزنار فوق ازارها. وقد روعى ان يكون من الوان متنوعة ووفق اللون المخصص للى طائفة

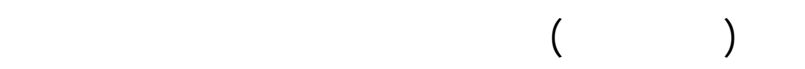
الذي يُربط حول الويط ويتلهط مُرفه من الأمل ويصل إلى

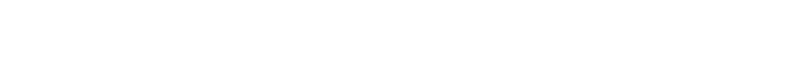

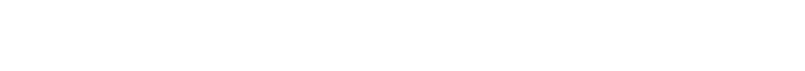

$$
\text { يغطى جزءََ من الوجه (نت -9) }
$$

- V

ثوب يلبس فوق الثيب والقباء مفتوح من الاملم وله كملن طويلان ضيقلن يضم الويط بطاق وهو من ملابس النساء المسلملت.

A 


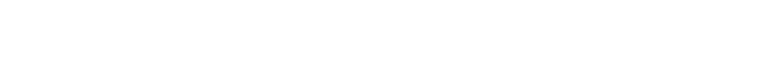

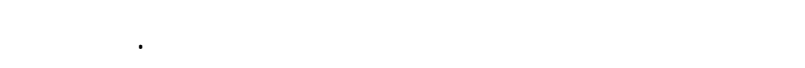

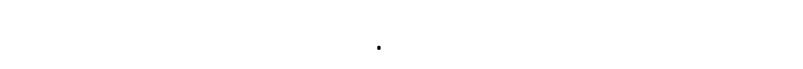

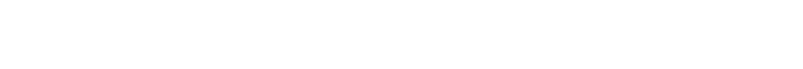
عليه فى صفف متتالية حق كاد الن يختى النسبج المصنوع منه البرقع

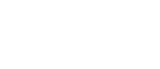

كالت لحنية النساء طابق في لشكالها وختتها لحنية

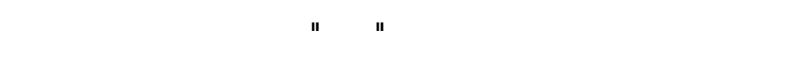

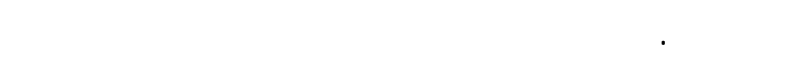

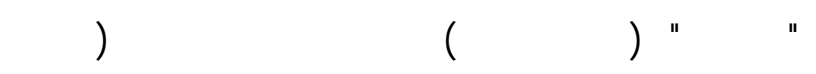

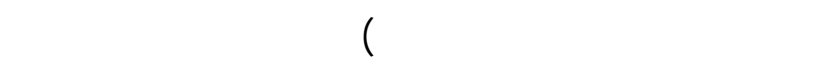

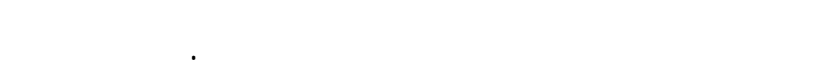

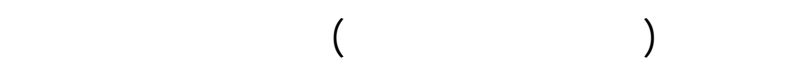

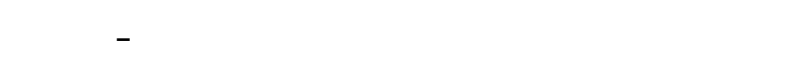

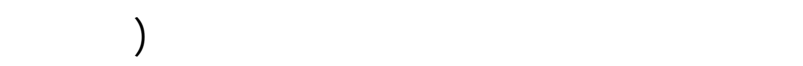
جr، صبم) وهـ نوع من الحذية القصيرة الق نسميه

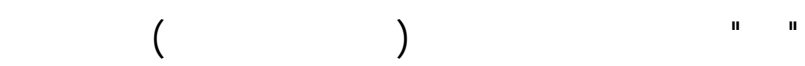

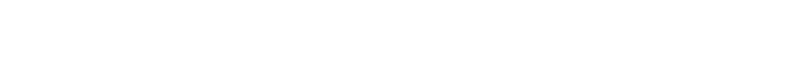

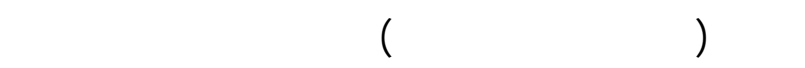

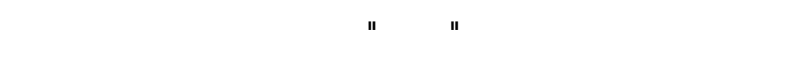

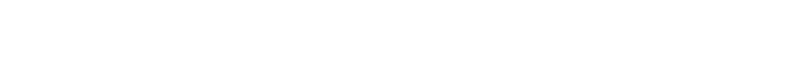

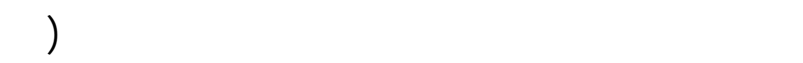

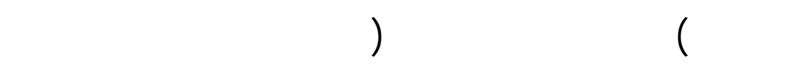

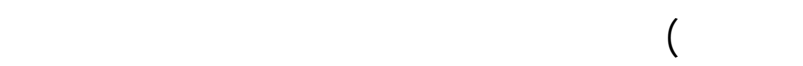

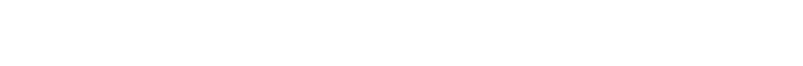

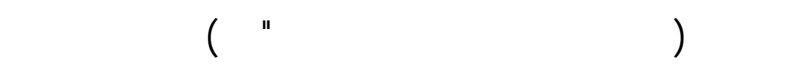

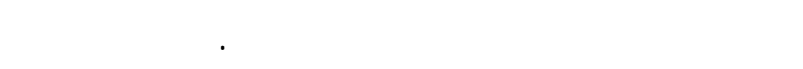

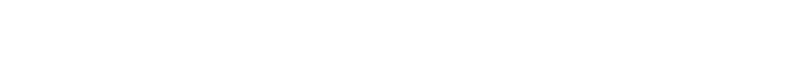

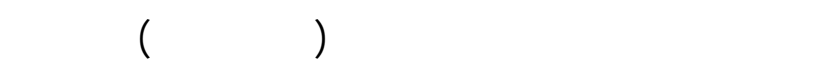

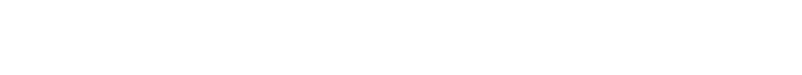

الخلمس عشر وحل محله "طرطور" طويل يظطيه ازار

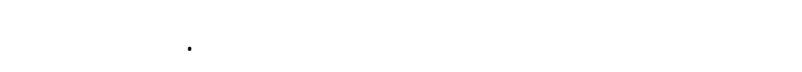

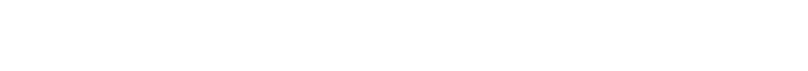

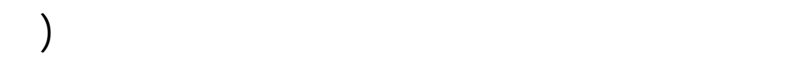

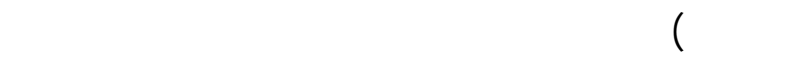

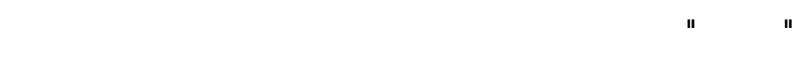

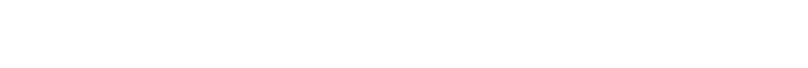
ذراع تقريبا. الما الطواقى فكالت مزينة بزخارف فخمة من جن الذهب والفضة (0، جr، صعاع · () لفنهة الوجه "القلب الو الخمار" وهو حجلب المرأة ويُسهى المقنعة اوالقناع أو البرقع المعارل

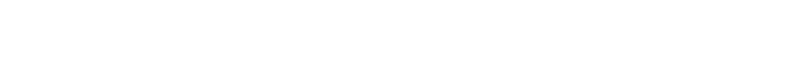

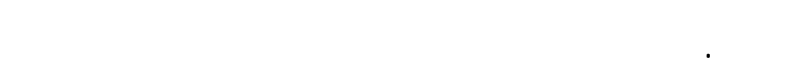

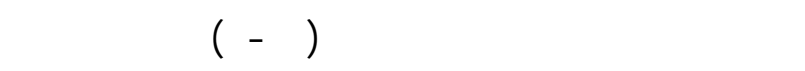

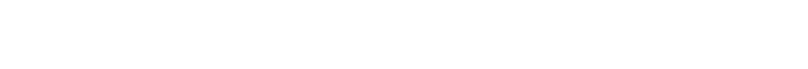

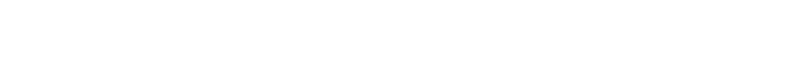

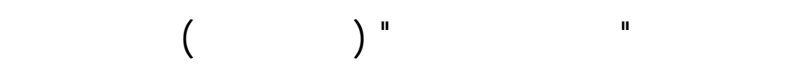
التعرف على نساء المومسلت من ملبسهن الخاص الذي التى

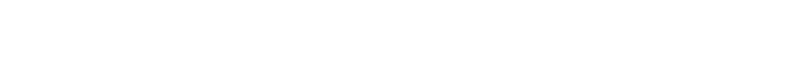

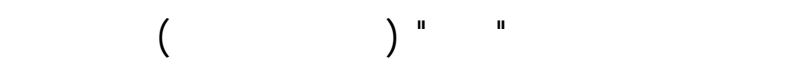
هذه الحجب: المقنعة- الطرحة- القناع- البرقع- القلب.

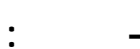

عبارة عن قناع شبكى خفف متوبط الطول يوضع جزء منه فوق الرئس "فوق الازار" مـ ينسل بقيته حق الحزلم مطيا لمل الوجه.

- الغناع: -

يشبه الحجلب ويزيد عنه ان به فتحتلن للعينان وهو مصنوع من قملش شبكى لمسود يططى الوجه كله وطالق عليه لحيانا لمبم القلب ـ وكان ظظهور المرئة بدون قناع دليل على فقرها للشديد 
وهو من الملابس الدلخلية للنساء وقد ورد فى قلموس المنجد" درع المرأة قميصها وهو قصير وله كملن ومخط المايط من الجانبين".

ع - المبسد

المجسد عبارة عن ثوب يلى جسد المرأة مباثرة، وهو

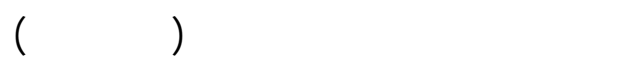

0

الغلالة عبارة عن ثوب مفرط ف الثفوف والخفة.

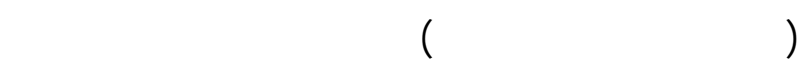

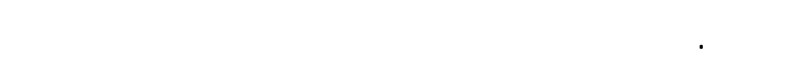

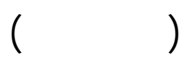

1 - البهلة من القمصان ذات نللطويل ينسل اله الارض ولكمل البهلة يبلغ لتساعها ثلاثة اذرع وقد بالغت النساء فى لتساع هذا النوع من القمصن . والمى جانب هذا النوع من القمصن الولسعة ارتدت البعض منهن قميص آخر ضضق لطلق عليها

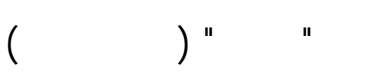

النتائج

- تعتبر الازياء من اهه المقوملت الحضارية لاى مجتمع التى يمكن الاعتماد عليها فى معرفة مدى نقهم وتلخر الخراء الثعوب وظهور الموضة.

- تميزت فترة حكم المماليك بالبزخ والترف وعرف عنهم حب التمتع بالحية وقدساعدهه على ذلك عدة عولهل

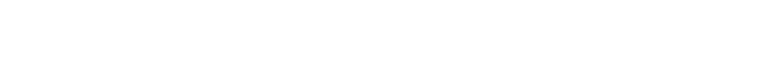

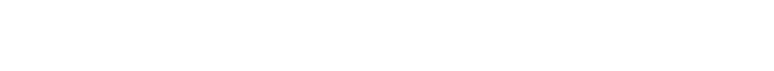

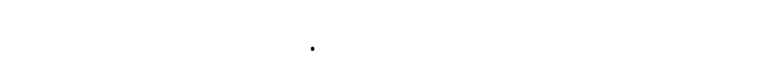
جمبع النولهى الحية للسيلسية والاقتصاية والاجتماعية. - يعتبر عصر المماليك عصر ازدهار والفتاح اقتصادي خصوصا فى صناعة الازياء والحرف المرتبطة بها مما ساهم فى التعرف على مفاهيم وقفافت مختلفة مما ادى في الدياء
والخلاخل الذهب والطاق والقلائد المرصعة بالاحجار

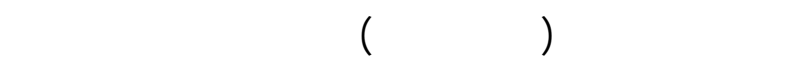

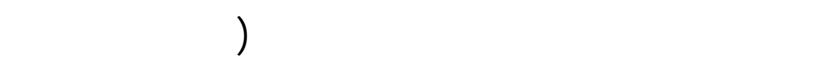

ص ص

\section{ملابس الدلخلية للنساء}

تعددت مسميت الملابس الدلخلية للنساء فى المرلجع التاريخية كالأتب والأصدة والقيرة والبهطلة والقنادير والدرع. وهذه المسميت كلها لمسم ولحد وهو القميص

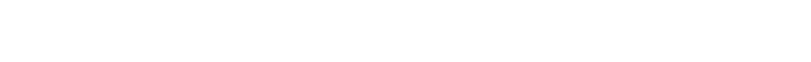

بدونها.

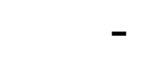

نوع من السراويل القصيرة وتسه لحيانا "بالتبلن " التى

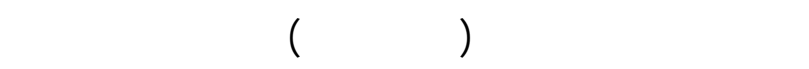
من الكلمة الفابسية شلوار. وكالت مستعملة منذ العهود

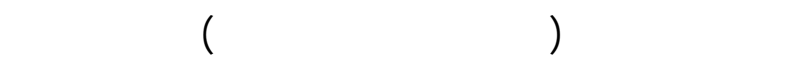
الطويل فقد لبستها النساء بسب حث الاسلام على لبسها.

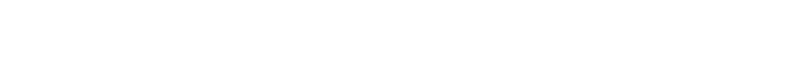
شجرة الدر الق مُ قتلها بولنطة جوارى الحريم بقصرها

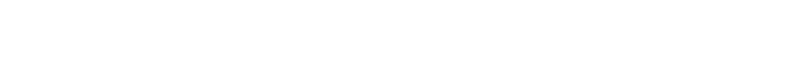

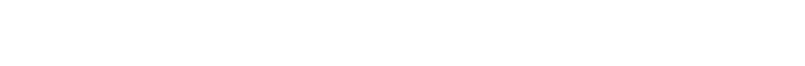

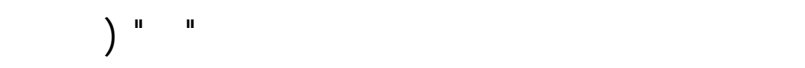

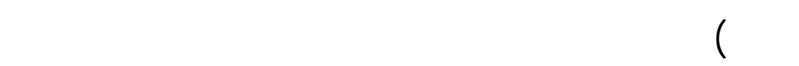

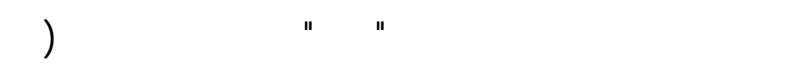
صن משת (1) r - أصسة التخذت النساء الأصة لبلسا دلخليا والأصدة بالضم عبارة عن قميص صغير يلبس تهت الثوب وهو صدار تلبسه الجارية. r - الدرع 
ثريا نصر، زينات طلحون " تاريخ الازياء" عالم الكتب -

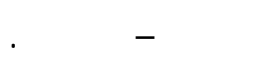

رينهارت دوزى "المعبم المفصل بلسٔماء الملابس عند العرب" ترجمة د.لكرم فاضل وزارة الاعلام بغداد

http://lisaanularab.blogspot.com/2012/06/blog-post_462.htm

ل.ا. ماير "الملابس المملوكية" ترجمة صالحشيق -الهيئة

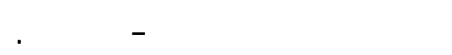

المقريزى "المواغظ والاعتبار فى نكر الخطط والآثار"

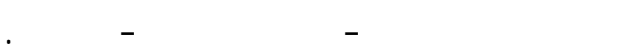

وداد حلمد "الأزياء للشعبية في مصر" موسوعة الفنون

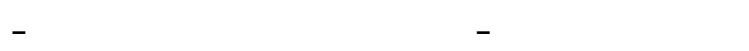

. $99 \varepsilon$

http://ar.wikipedia.org/wiki/\%D8\%A3\%D9\%84\%D9\%82\%D

$8 \% \mathrm{~A} 7 \% \mathrm{D} 8 \% \mathrm{~A} 8 \% \mathrm{D} 9 \% 88 \% \mathrm{D} \% \% 85 \% \mathrm{D} 8 \% \mathrm{~B} 5 \% \mathrm{D} 8 \% \mathrm{~B} 7$

$\%$

D9\%84\%D8\%AD\%D8\%A7\%D8\%AA_\%D9\%85\%D9\%8 5\%D9\%84\%D9\%88\%D9\%83\%D9\%8A\%D8\%A9

http://ar.wikipedia.org/wiki/\%D9\%85\%D9\%85\%D8\%A7\%D

9\%84\%D9\%8A\%D9\%83 \%D9\%85\%D8\%B5\%D8\%B1

http://taree5.wordpress.com/2012/03/19/\%D8\%A3\%D8\%B2

\%D9\%8A\%D8\%A7\%D8\%A1\%D8\%A7\%D9\%84\%D9\%

$85 \% \mathrm{D} 9 \% 85 \% \mathrm{D} 8 \% \mathrm{~A} 7 \% \mathrm{D} 9 \% 84 \% \mathrm{D} 9 \% 8 \mathrm{~A} \% \mathrm{D} 9 \% 83 /$

http://www.alittihad.ae/details.php?id=75018\&y=2011\&article $=$ full

http://www.almasalik.com/locationPassage.do?locationId=2985 4\&language $I d=$ ar\&passage $I d=9939$

http://www.wesaltv.net/vb/showthread.php?t=19724
اللى فتح مجل الابتكار والاقتبلس فى مجل تصميم

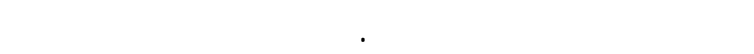
المواصفلت وشروط تختلف من زى لاخر، وذلك تبعا للاظاف المختلفة دلغل البلاط للسطانف. فالزى يختلف من المير اله الوزير اللى رئيس الديوان اللى الجند فلكل منهم زيه الخاص من حيث الخلمة والفصل والفيل اللإن. وكذك الحل بالنبة لنسائهم. - يشكل مرجعا غاية في الأهمية في تاريخ الازياء العربية وطورها. - يسهم في فه تاريخ اللبلس العربي والإسلادي عبر العصور.

\section{التوصيلت}

- توصص البلحثة بشتجبع البلحيثين والداوسين على الخوض فى هذا المجل وذك لمد نولئ القص فى المكتبة العربية

- توصى البلحثة بلشاء عدة متلف خاصة بالازياء وتوصيف النمط تلك الازياء.

- الصدار قلموس لشرح مسميت الازياء وكفية فصيلها فـ العصور اللسلمية. ع الجأin

إبراهيم محمد هسين "الأزياء للشعبية في الوادي الجديد"

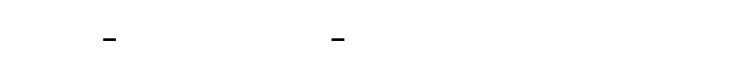
العالي للفنون الشعبية - بو ام.

\section{SUMMARY}




\title{
Historical, Analytical Study of Models Mamluk Fashion
}

\author{
Riham Youssef Ameen Al- Anany
}

The study of the history of fashion from the important studies generally, It reflects the material culture such as architecture and arts, Our knowledge of the Mamluk fashion is derived from Arab historical sources and archaeological books of travelers and jurisprudence and language dictionaries, as well as from the correspondence government employees. The subject of Mamluk fashion of the two types of civil and military,are from the of important topics in the history of the Arab Islamic civilization, because fashion generally is an important heritage containing elements of material and technical heritage, Which is not less important than any research. the study of any heritage regardless of the value of artistic and intellectual together. The study of the Mamluk costumes are closely linked to the customs and traditions of that period, especially in times of occasions and holidays and various celebrations, which sets us how to wear these outfits. 